\title{
A rundown of merger target run-ups
}

\author{
Marie Dutordoir $^{1}$ | Evangelos Vagenas-Nanos ${ }^{2}$ \\ Patrick Verwijmeren $^{2,3,4}$ | Betty $\mathbf{W u}^{2}$
}

\author{
${ }^{1}$ Alliance Manchester Business School, \\ University of Manchester, Manchester, UK \\ ${ }^{2}$ Adam Smith Business School, University of \\ Glasgow, Glasgow, UK \\ ${ }^{3}$ Erasmus School of Economics, Erasmus \\ University Rotterdam, Rotterdam, The \\ Netherlands \\ ${ }^{4}$ The Department of Finance, University of \\ Melbourne, Melbourne, Australia

\section{Correspondence} \\ Marie Dutordoir, Alliance Manchester Busi- \\ ness School, University of Manchester, Manch- \\ ester M139PL, UK. \\ Email:marie.dutordoir@mbs.ac.uk
}

\begin{abstract}
We provide evidence of a drastic drop in stock run-ups of U.S. target firms preceding merger and acquisition (M\&A) announcements over the past decades. The median target run-up declines from approximately $10 \%$ in the 1980 s to $2 \%$ after 2010. The trend in target run-ups cannot be fully explained by deal or firm characteristics associated with deal anticipation. However, it disappears after controlling for changes in the strength of U.S. insider trading regulation over the research period. Further analyses corroborate our conclusion that more stringent insider trading regulation is the most likely explanation for the reduction in target run-ups.
\end{abstract}

\section{1 | INTRODUCTION}

It is well established in the corporate finance literature that target firm stock prices tend to increase substantially before merger and acquisition (M\&A) announcements (Weston, Mitchell, \& Mulherin, 2014). Studies on this topic consistently find positive average preannouncement target abnormal stock returns (i.e., target run-ups) in the area of $10 \%$ representing approximately half of the total M\&A stock price effect for target firms (Dennis \& McConnell, 1986; Dodd, 1980; Keown \& Pinkerton, 1981; Meulbroek, 1992; Schwert, 1996).

In this paper, we find that U.S. target run-ups have been declining steadily and significantly since the research period covered by most previous studies on this topic. While we observe run-ups similar in magnitude to other studies for the early 1980s, the median target run-up over the final years covered by our study, 2010-2018, is only $2.18 \%$. We further report a significant increase in target abnormal stock returns around deal announcement dates. Total (preannouncement plus announcement) stock price effects of $M \& A$ deals for target firms do not change significantly over time.

This is an open access article under the terms of the Creative Commons Attribution-NonCommercial-NoDerivs License, which permits use and distribution in any medium, provided the original work is properly cited, the use is non-commercial and no modifications or adaptations are made.

(c) 2020 Financial Management Association International 
We examine whether the decrease in target run-ups can be attributed to changes in deal and firm characteristics associated with the degree to which market participants can anticipate mergers as per the "deal anticipation" explanation for target run-ups (Asquith, 1983; Jensen \& Ruback, 1983). We find that the negative trend in target run-ups persists when we split deals in subsamples according to deal anticipation proxies suggested by the literature (Ambrose \& Megginson, 1992; Espahbodi \& Espahbodi, 2003; Jarrell \& Poulsen, 1989; Karpoff, Schonlau, \& Wehrly, 2017; Palepu, 1986). This trend is not driven by a higher occurrence of deals without predeal rumors, deals without prebid toehold stakes in recent years, or deals with single bidders. Similarly, the negative trend holds across targets with high and low market-to-book ratios and across large and small targets. Regressions of target run-ups consistently demonstrate a negative time trend, even when including a wide range of deal anticipation proxies. Moreover, predicted target run-ups generated by a regression model with deal- and firm-specific independent variables systematically fail to completely capture the decrease in actual run-ups.

We subsequently examine whether the negative trend in target run-ups can be attributed to the increasingly stringent insider trading regulations adopted in the United States over the research window. These rules could have curbed insiders' potential to perform illegal trades based on knowledge of upcoming deals (Keown \& Pinkerton, 1981; Meulbroek, 1992). We focus on four important changes in insider trading regulations over the research period (i.e., IT events). We find that after controlling for the adoption of these regulatory changes, the time trend in the run-ups is no longer significant.

We conduct several tests to verify that the observed link between insider trading regulations and target run-ups is not spurious. First, we zoom in on a smaller sample of deals announced immediately prior to and following the four IT events. The median preannouncement target run-up for deals announced during the 180-day period prior to the first IT event is $11.61 \%$. The median target run-up falls to $8.36 \%$ for deals announced shortly after the enactment of that first regulation. Similarly, median target run-ups around the second IT event decline from 5.81\% to $4.49 \%$ and around the third IT event from $3.71 \%$ to $1.52 \%$. We observe median target run-ups of only $0.90 \%$ shortly after the fourth IT event.

In addition, we exploit cross-sectional differences in the probability of insider trading. We find that the negative impact of insider trading rules on target run-ups is stronger for deals with a larger number of target advisors. This finding is consistent with these deals having a higher probability of provoking preannouncement insider trading (Dai, Massoud, Nandy, \& Saunders, 2017) and is not easily explained by any omitted unobservable force unrelated to insider trading.

Moreover, we examine target shareholders' posterior probability of informed trading on positive information

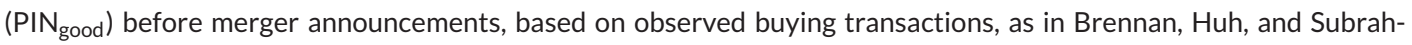
manyam (2018). We find a declining trend in premerger PIN $_{\text {good }}$ values over our research window. We then determine that the negative trend in premerger PIN $_{\text {good }}$ values disappears when controlling for changes in insider trading regulation over the research period, consistent with increased regulation being successful at curbing premerger insider trading.

We also conduct a placebo test on a sample of M\&A deals for Canadian firms that are subject to much less stringent insider trading rules than their U.S. counterparts (Bris, 2005). We find that U.S. insider trading regulations do not reduce target run-ups for these foreign deals suggesting that the observed relation between the timing of these regulations and the trend in U.S. target run-ups is not driven by omitted macroeconomic variables.

Our paper is relevant for corporate managers by providing new insight that the prevailing assumptions regarding the magnitude of target run-ups, based on older empirical studies, needs to be revised. Target run-ups have substantially declined over time, and our study analyzes potential explanations for this observed phenomenon. Our findings may also be useful for policy makers and regulators by suggesting that more stringent insider trading rules have curbed premerger target run-ups.

The remainder of the paper is structured as follows. Section 2 positions our work within the literature and outlines its contributions. Section 3 describes the sample construction and measurement of the target run-ups and documents 
the trend in run-ups over our sample period. Section 4 explores potential explanations for this trend. Section 5 discusses additional analyses, while Section 6 provides our conclusions.

\section{2 | LITERATURE REVIEW}

The literature proposes two non-mutually exclusive explanations for target run-ups. The deal anticipation hypothesis argues that these run-ups are driven by legal trading by informed market participants, such as proprietary traders and risk arbitrageurs, who expect that certain firms will be the target of an upcoming deal (Jensen \& Ruback, 1983). Market participants' expectations regarding upcoming deals may be based on information in press releases, mandated disclosures, comments by "shark watchers," and observations of activity by merger arbitrageurs (Jabbour, Jalilvand, \& Switzer, 2000).

The "insider trading" hypothesis, in turn, argues that target run-ups are caused by illegal trading from corporate insiders who know about the upcoming M\&A deal ahead of the rest of the market (Keown \& Pinkerton, 1981). Insider trading is restricted by Sections 10(b) and 14(e) of the Securities Exchange Act of 1934, and Rules 10b-5 and 14e-3 thereunder. According to court interpretations of these rules, there are four essential requirements for trades to qualify as illegal insider trading (Netter, Poulsen, \& Hersch, 1988). First, the trade must be done by a corporate insider. In addition, the insider must trade on material inside information. Information is material if there is a substantial likelihood that a reasonable investor would consider it important in their investment decision (Jarrell \& Poulsen, 1989). Moreover, the transaction must involve a purchase or sale of a security. Finally, there must be evidence of an intention to deceive, manipulate, or defraud. Although media sources regularly report about penalties given for high profileinsider trading offenses, academic studies find that insider trading often goes unpunished (Bhattacharya \& Daouk, 2002; Bris, 2005). Schwert (1996) argues that merger announcements are particularly challenging for regulatory authorities trying to curb illegal trading practices. The reasons are twofold. First, mergers typically involve significant price-sensitive information increasing potential profits associated with illegal trading. In addition, M\&A planning tends to involve a wide circle of people (e.g., lawyers, consultants, target firm employees, and regulators), all of whom possess material inside information. Thus, target run-ups could be caused by illegal insider trading.

Empirical evidence for the two above explanations for target run-ups is mixed and inconclusive. Early studies primarily focus on testing one of the two explanations. Consistent with the deal anticipation hypothesis, Jarrell and Poulsen (1989) find that target run-ups and trading volumes before tender offer announcements are associated with several observable and legal factors, such as the presence of media rumors about an impending bid. Jarrell and Poulsen (1989, p. 226) conclude that "to argue that pre-bid run-ups necessarily reflect insider trading (...) is a misrepresentation of the data." Also in line with the deal anticipation hypothesis, Gupta and Misra (1989) find that stock price runups for firms mentioned in the news as potential M\&A targets are larger than those for "no news" firms. However, they acknowledge that they cannot completely rule out insider trading as a potential explanation for target run-ups. Betton, Eckbo, Thompson, and Thorburn's (2014) large sample analysis supports rational deal anticipation as a driver of target run-ups, while rejecting a costly feedback loop from run-ups to offer prices.

Consistent with an insider trading explanation for run-ups, Keown and Pinkerton (1981, p. 855) allege that "impending merger announcements are poorly held secrets, and trading on this non-public information abounds." They do not formally test whether corporate insiders effectively cause preannouncement trading. Meulbroek (1992) makes headway on this question by using Securities and Exchange Commission (SEC) data on illegal insider trading. She finds that almost half of the target run-up tends to occur on days with insider trading. Chakravarty and McConnell (1999), however, determine that the effect of insiders on stock prices is not significantly different from that of noninsiders and argue that studies should jointly examine insider and noninsider transactions. Brennan et al. (2018) obtain evidence consistent with informed premerger trading by using daily posterior probabilities of informed buying and selling obtained from information on individual trades. Bodnaruk, Massa, and Simonov (2009) and Lowry, Rossi, and Zhu (2018) note insider trading activity among M\&A bidder advisors. More generally, Bhattacharya, Daouk, Jorgenson, and 
Kehr (2000) focus on a wider range of corporate announcements in a Mexican setting, where differences between A and $B$ class shares allow them to disentangle anticipation from an insider trading explanation for preannouncement stock price movement. Their findings suggest widespread insider trading prior to corporate announcements. Also consistent with an insider trading explanation, Del Guercio, Odders-White, and Ready (2017) find a negative relation between staff and budget resources available to the SEC from 2003 to 2011 and run-ups before major corporate announcements including takeovers.

To conclude, while previous studies provide evidence supporting both deal anticipation and insider trading, there is no clarity yet on the relative importance of these explanations for target run-ups. Our paper contributes to the literature by documenting and explaining the declining trend in target run-ups from the 1980s, the period covered by most previous studies, until $2018 .{ }^{1}$ Our long research window enables us to exploit the increasingly stringent insider trading regulations in the United States over time. We control for a wide range of deal- and firm-specific proxies suggested by the literature, allowing us to test the relative importance of deal anticipation and insider trading explanations for target run-ups.

\section{I SAMPLE CONSTRUCTION AND TARGET RUN-UPS}

This section describes the data set of $M \& A$ deals, the measurement of target run-ups, and the evolution of abnormal stock returns for the target firms over our sample period.

\section{1 | Sample}

The sample consists of M\&As in which U.S. domiciled firms (labeled "bidders") acquire U.S. domiciled publicly held firms (labeled "targets"). The research period is January 1985 to December 2018. We obtain deals from Thomson ONE. For deals to be retained in the final sample, the following standard inclusion criteria must apply (Cao, Li, \& Liu, 2019; Fuller, Netter, \& Stegemoller, 2002; Golubov, Petmezas, \& Travlos, 2016; Martin, 1996): The bidder purchases at least 50\% of the target shares, the deal value is at least $1 \%$ of the market value of the bidder, the market value of the target firm is at least $\$ 1$ million, the deal is not withdrawn, and the target firm's stock price data are available from the Center for Research in Security Prices (CRSP) over the year prior to the deal announcement. ${ }^{2}$ Private bidders include private equity and private operating firms. We remove privately held bidder deals with "Investor Group," "Bondholders," "Creditors," or "Shareholders" instead of a firm name listed as "Acquirer Name" in Thomson ONE since we focus on bidding firms, not groups of investors (Bargeron, Schlingemann, Stulz, \& Zutter, 2008). After imposing these criteria, we obtain an initial sample consisting of 7,962 M\&A deals.

In a subsequent step, we eliminate deals with missing values for the deal anticipation proxies discussed in the next section. One of the deal anticipation proxies, Target-bidder ratio, has bidder total assets as its denominator. This variable is missing in Thomson ONE and Capital IQ for 474 of 564 deals with private bidders. ${ }^{3}$ To avoid a large loss of privately held bidder deals from the onset of our empirical tests, we do not require the availability of Target-bidder ratio for the univariate analyses. We obtain a sample of 2,816 M\&A deals for the univariate tests. Our baseline regression analyses include Target-bidder ratio as a (significant) control variable leading to a reduced final sample size of 2,279 deals. ${ }^{4}$ In

\footnotetext{
${ }^{1}$ Betton et al. (2014, table 3) report the annual distribution of target run-ups for U.S. M\&As from 1980 to 2008 as part of their descriptive statistics. They also document smaller run-ups toward the end of their sample period. However, they do not mention or attempt to explain the decline in target run-ups over time.

2 By construction, we can only impose this criterion for public bidders. Our baseline results do not materially change when we remove this constraint.

${ }^{3}$ We were able to obtain bidder total assets from Thomson ONE for 23 private bidders. We found total assets for an additional 67 private bidders on Capital IQ, bringing the total of private bidders to 90 .

4 Target-bidder ratio is missing for 63 deals with publicly held bidders.
} 
robustness tests described further, we verify that our regression results remain similar when we do not include Targetbidder ratio as a control variable enabling us to use the larger sample of 2,816 deals.

\section{2 | Measuring target run-ups}

We use market model regressions to estimate abnormal stock returns. We estimate the regressions over a period of 190 trading days ending at trading day -76 relative to the deal's announcement date retrieved from Thomson ONE. We use the CRSP equally weighted index as a proxy for the market portfolio. We define our main target runup measure as the cumulative abnormal stock return over the 20 trading days before the deal announcement date. Several previous studies use a similar time window for calculating target run-ups (Dennis \& McConnell, 1986; Jarrell $\&$ Poulsen, 1989). In robustness tests discussed below, we use alternative run-up measures suggested by the literature. We winsorize target run-ups, as well as continuous control variables at the $5 \%$ and $95 \%$ levels to avoid outliers affecting the results. Our results remain similar when we winsorize at the $1 \%$ and $99 \%$ levels.

\section{3 | Trend in target run-ups}

Figure 1 plots median target run-ups over five-year intervals within the research period. The final interval is nine years long as our sample period ends in 2018. In line with previous studies, the figure reports evidence of positive target abnormal stock returns prior to $M \& A$ announcement dates. However, run-ups clearly become substantially smaller in more recent intervals. Average run-ups, which we do not show for brevity, show a similar trend.

Table 1, Panel A, provides quantitative evidence of the evolution in target run-ups over time. It gives a breakdown of average and median run-ups over each of the intervals. Column (1) reports an average abnormal stock return of approximately $10 \%$ for the earliest time period (1985-1989), consistent with the magnitude of target run-ups reported in prior studies (Keown \& Pinkerton, 1981; Meulbroek, 1992; Schwert, 1996). Average target run-ups tend to become smaller over time. At the end of the sample period (2010-2018), we find average run-ups of only $3.75 \%$. Median runups show a similar pattern, steadily dropping from $9.02 \%$ in the initial interval to $2.18 \%$ in the most recent interval. We note that there are no further declines between 2005-2009 and 2010-2018. Regressing the run-ups on a yearly time trend variable and an intercept, we find a significant negative annual time trend of $-0.26 \%$ for average run-ups and $-0.25 \%$ for median run-ups.

We also consider target run-ups over a longer window. Sixty trading days before the announcement date seems to be the longest preannouncement window considered in the run-up literature (Brigida \& Madura, 2012; Keown \& Pinkerton, 1981), so we use this window as an alternative run-up measure. As Column (2) indicates, we find a similar pattern for this measure.

Event studies based on older data often include the return on trading day -1 as part of the announcement effect. The rationale behind this practice is that there may be a one-day time lag between the actual announcement of the news by the company and the publication of that announcement in outlets such as the Wall Street Journal. This time lag is likely to be more prevalent for the first decades of our sample period, as investors did not yet heavily rely on electronic news sources during those earlier years. To verify that the target run-up measure does not reflect the news of the public announcement of the merger on the trading day immediately before day 0 , we redefine it as the abnormal target stock return over trading days -20 to -2 prior to the merger announcement. As Column (3) indicates, our findings remain similar to those for the original run-up measure. In the remainder of the paper, we measure target run-ups over trading days -20 to -1 .

Next, we verify whether there is any trend in target announcement returns over the research period. We measure these over the M\&A announcement date and the subsequent trading day to account for announcements that have been made after stock market closure or on a nontrading day. Column (4) presents a positive trend in target 


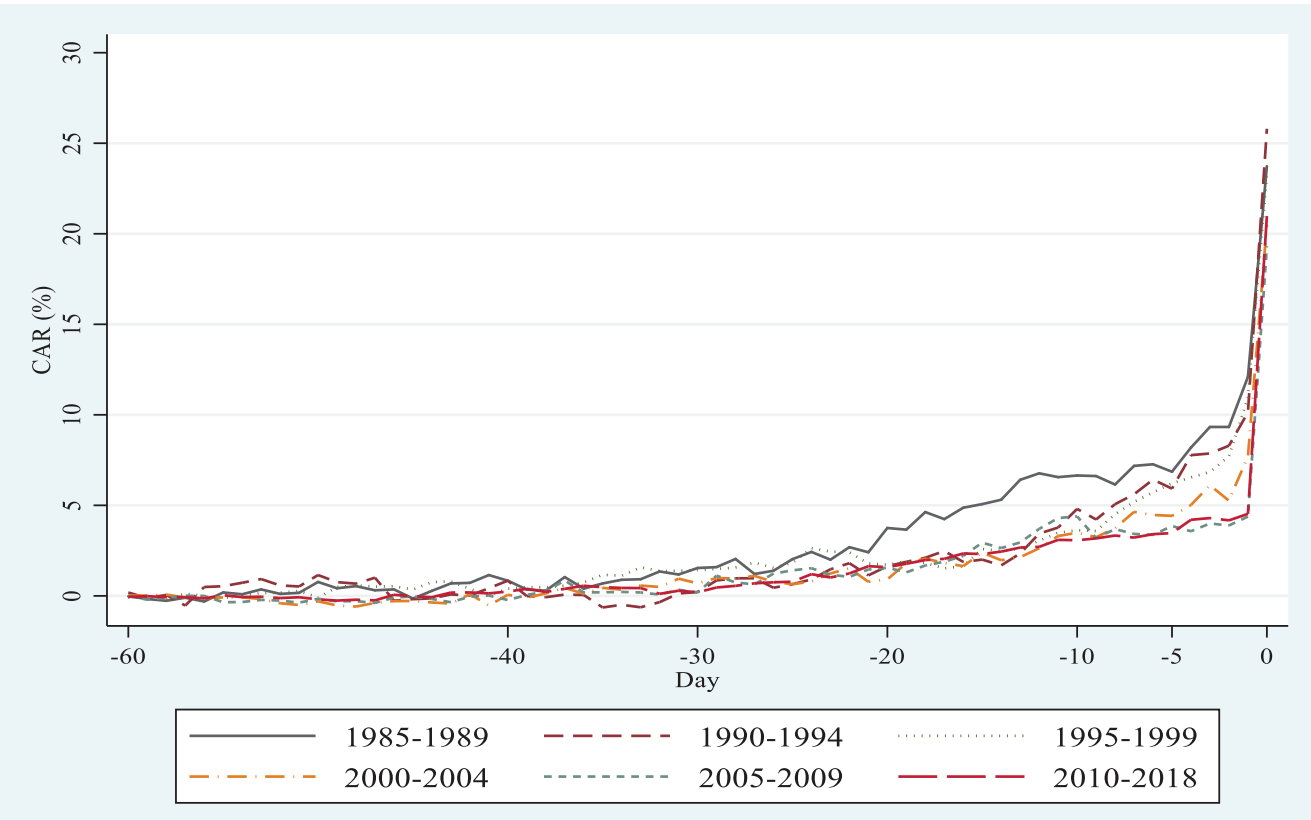

FIGURE 1 Median target stock run-ups over six subperiods of the research period [Color figure can be viewed at wileyonlinelibrary.com]

Note. This figure reports the median daily target firm abnormal stock returns for six subperiods within our research window of 1985-2018. The sample consists of 2,816 M\&As involving U.S. bidder and target firms from 1985 to 2018 obtained from Thomson ONE. Days represent trading days relative to the $M \& A$ announcement date retrieved from Thomson ONE. Abnormal stock returns are estimated with market model regressions. We estimate these regressions over a period of 190 days ending on day -76 relative to the announcement date. We use the CRSP equally weighted index as a proxy for the market portfolio.

announcement returns. Average (median) returns increase from 15.35\% (12.52\%) from 1985 to 1989 to $23.01 \%$ (19.46\%) from 2010 to 2018. Combined with the findings in Columns (1)-(3), this pattern suggests that the decline in target run-ups is compensated by an increase in announcement period returns. Corroborating this insight, Column (5) indicates that total (preannouncement plus announcement period) stock price effects for the target firms remain largely stable over time. Accordingly, we do not find a significant time trend for the average or median total returns.

Some studies consider run-up index measures, constructed as the ratio of target run-ups to total M\&A-related stock price effects (Bris, 2005; Jarrell \& Poulsen, 1989). In line with these studies, we present run-up index ratios in Column (6). Consistent with the results reported in the previous columns, we find that the proportion of target run-ups relative to total stock price effects steadily decreases over time with a statistically significant negative time trend both for the average and median ratios. In particular, while the median ratio is higher than $40 \%$ at the start of our research period, which is consistent with previous studies (Jarrell \& Poulsen, 1989; Meulbroek, 1992), it drops to approximately 10\% toward the end of our research period.

\section{$4 \quad$ I POTENTIAL EXPLANATIONS FOR THE TREND IN TARGET RUN-UPS}

This section examines potential reasons for the significant decline in target run-ups over the past decades. We begin by exploring the deal anticipation hypothesis and then turn to changes in insider trading as a potential explanation. 


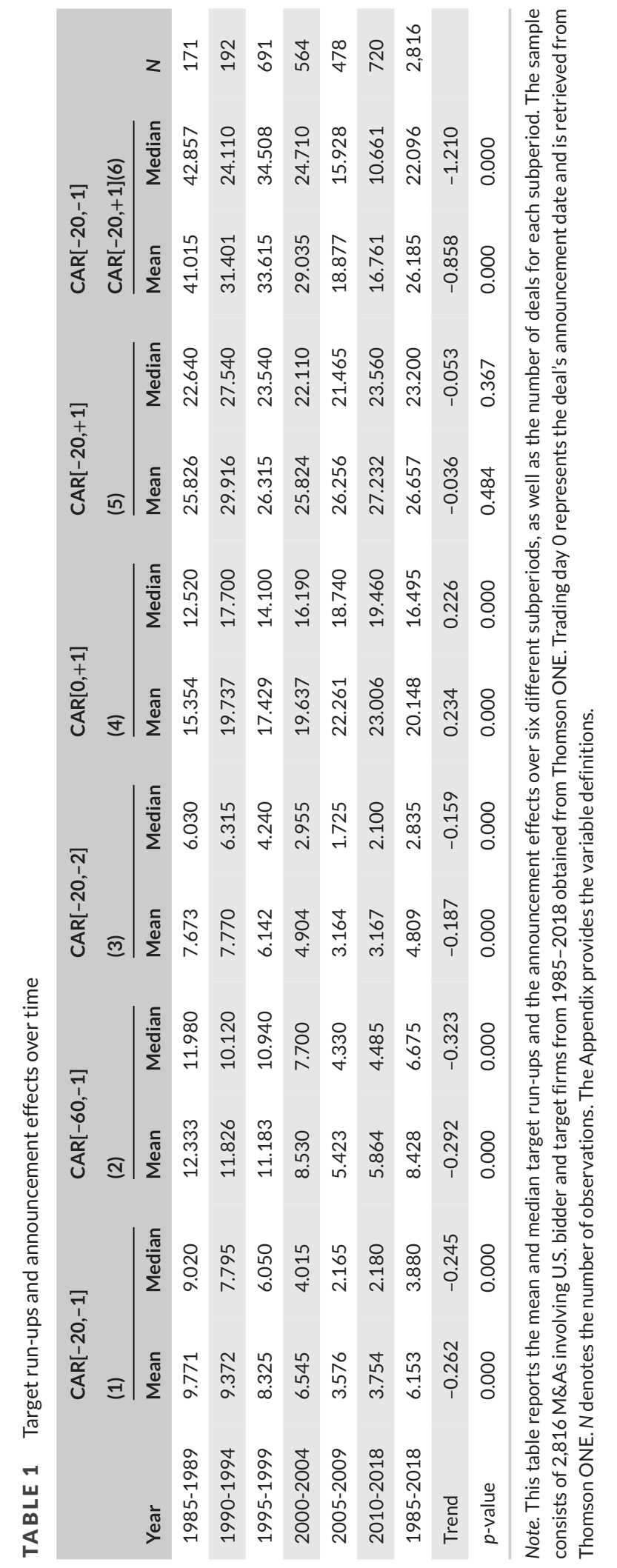




\section{1 | Deal anticipation hypothesis}

According to the deal anticipation hypothesis, target run-ups are caused by legal trading activity by market participants who can predict targets of upcoming deals. From this viewpoint, the decline in target run-ups could result from a reduced ability of informed traders to anticipate future targets based on publicly available information. One potential reason for a reduction in target predictability is that deal or firm characteristics associated with investors' ability to anticipate deals have changed over time. To examine this possibility, we analyze whether the trend in target runups persists after controlling for variables associated with a greater likelihood of deal anticipation by investors. The Appendix provides detailed definitions of all of the variables and their sources.

We construct the following deal anticipation proxies suggested by the literature using information from Thomson ONE:

Rumor: A dummy variable capturing whether there have been media rumors about the deal before its official announcement. Deals preceded by rumors are likely to be more anticipated by the market (Gupta \& Misra, 1989).

Toehold: A dummy variable equal to one when the bidder has an equity stake in the target firm before the deal announcement. A pre-M\&A equity stake may signal a takeover intention and make the deal more predictable (Betton et al., 2014; Brigida \& Madura, 2012). Alternatively, a toehold stake tends to decrease the remaining target shareholders' takeover gains, which might reduce the probability of an eventual takeover taking place (Stulz, Walkling, \& Song, 1990). The impact of the Toehold dummy variable on the likelihood of a deal is therefore unclear.

Cash financing: Measures the percentage of cash financing for the target firm. Cash-financed deals could be more anticipated (Brigida \& Madura, 2012) as firms often must raise debt financing through bank syndicates to obtain the cash payments required for a deal. Syndicates could foster a large degree of premerger information exploitation (Acharya \& Johnson, 2010). Alternatively, stock-financed deals could be more anticipated due to the negotiation and potential shareholder approval associated with these deals.

Hostile: A dummy variable equal to one for hostile deals. Hostile bidders typically try to make the bid a surprise in order to reduce the target's potential to activate takeover defenses. Under this scenario, hostile bids may be less anticipated than friendly bids, which tend to involve predeal negotiations increasing the likelihood that the market learns about the deal before its official announcement. However, some hostile bidders attempt to place target firm stocks in the hands of arbitrageurs, who are typically more willing to tender their shares. Under this scenario, hostile bids might be more anticipated than friendly bids. The relation between the hostile nature of bids and their anticipation is therefore unclear (Jarrell \& Poulsen, 1989).

Poison pill: A dummy variable equal to one for targets with a poison pill provision in place. Investors might expect firms with poison pill takeover defenses could be less likely to become a takeover target (Malatesta \& Walkling, 1988), although Comment and Schwert (1995) find that poison pill rights typically do not deter takeovers. Number of bidders: If more firms are interested in the target, the deal is more likely to be anticipated.

We also construct the following standard target-specific deal anticipation determinants using Compustat balance sheet and CRSP stock price data:

Market-to-book: Firms with low market-to-book ratios are often perceived as cheap, even though the book value of assets does not necessarily reflect their replacement value (Palepu, 1986). Moreover, lower market-tobook ratios could indicate low growth opportunities suggesting shareholder value can be improved through a takeover (Espahbodi \& Espahbodi, 2003). Thus, a low market-to-book value should be associated with a higher anticipated likelihood of becoming a target firm. 
FCF: Measures free cash flow over total assets. Firms with greater values for this ratio tend to have lower investment opportunities and more agency problems (Jensen, 1986). As such, these firms are more likely to be taken over by acquirers who spot room for improvement (Espahbodi \& Espahbodi, 2003).

Dividend yield: Firms with a high dividend yield typically have fewer growth opportunities, higher agency costs, and more financial constraints making them more likely to be targeted for an M\&A deal (Espahbodi \& Espahbodi, 2003). Higher dividend payments could also reduce the opportunity costs for investors to purchase target stocks before merger announcements.

Sales growth: This variable acts as a measure of firm growth and should be negatively related to the odds of being targeted for a takeover (Espahbodi \& Espahbodi, 2003).

Growth-resource (GR) mismatch: This variable is inspired by the GR imbalance hypothesis that indicates growth (as captured by changes in sales) and resource availability (as captured by leverage and cash reserves) are important drivers of a firm's likelihood of becoming a takeover target. In particular, firms with high growth and low liquidity, or low growth and high liquidity, are more likely to be taken over (Palepu, 1986). The GR mismatch dummy is equal to one for these firms and zero otherwise.

Leverage: In addition to the GR mismatch dummy variable, we also separately control for target leverage and liquidity (described below). Firms with high leverage are typically less attractive as takeover targets as an acquisition of low debt firms is less costly to finance (Song \& Walkling, 2000).

Liquidity: Measured by cash reserves. Firms with higher cash reserves have a greater likelihood of being acquired as there is an opportunity for the bidders to finance the acquisition with the target's own resources (Espahbodi \& Espahbodi, 2003; Song \& Walkling, 1993).

Firm size: Captures the size of the target firm as measured by total assets converted into constant 1980s U.S. dollars using the U.S. Consumer Price Index obtained from Datastream. Smaller firms are more likely to end up as targets for M\&A deals (Ambrose \& Megginson, 1992; Song \& Walkling, 2000).

Historical stock return: Consistent with Palepu (1986), we use excess stock returns over the past four years as a proxy for management efficiency. Firms managed by inefficient managers are more likely to be taken over. Hence, this variable has a negative predicted association with deal anticipation as lower historical stock returns should reflect a greater likelihood of being acquired.

State: Dummy variable equal to one for firms incorporated in Delaware. This state has the toughest antitakeover laws in the United States, which could potentially make its incumbent firms less likely to be targeted (Espahbodi \& Espahbodi, 2003), although Comment and Schwert (1995) find only weak evidence for any mitigating impact of antitakeover laws on takeover frequency.

Finally, we include two further control variables in the target run-up analysis:

Private bidder: While we do not have a clear prediction as to whether deals with privately held bidders are more likely to be anticipated, privately held bidders are typically more disciplined in their bidding, leading to smaller anticipated premiums and, as such, lower predicted target run-ups (Bargeron et al., 2008).

Target-bidder ratio: Measures the relative sizes of the target and bidding firms and can capture deal complexity and postmerger integration costs (Alexandridis, Fuller, Terhaar, \& Travlos, 2013; Malmendier, Moretti, \& Peters, 2018). We do not have clear expectations for the relation of this variable with deal anticipation either.

Table 2 reports the median target run-up values for subsamples split according to the above characteristics. For binary deal and firm characteristics, the split is straightforward. For continuous characteristics, we split the sample into subsamples based on their median value.

Column (1) creates subsamples using deals over the entire sample period. The values in italics below the full period target run-up medians represent the differences in the median target run-up values between each pair of subsamples 


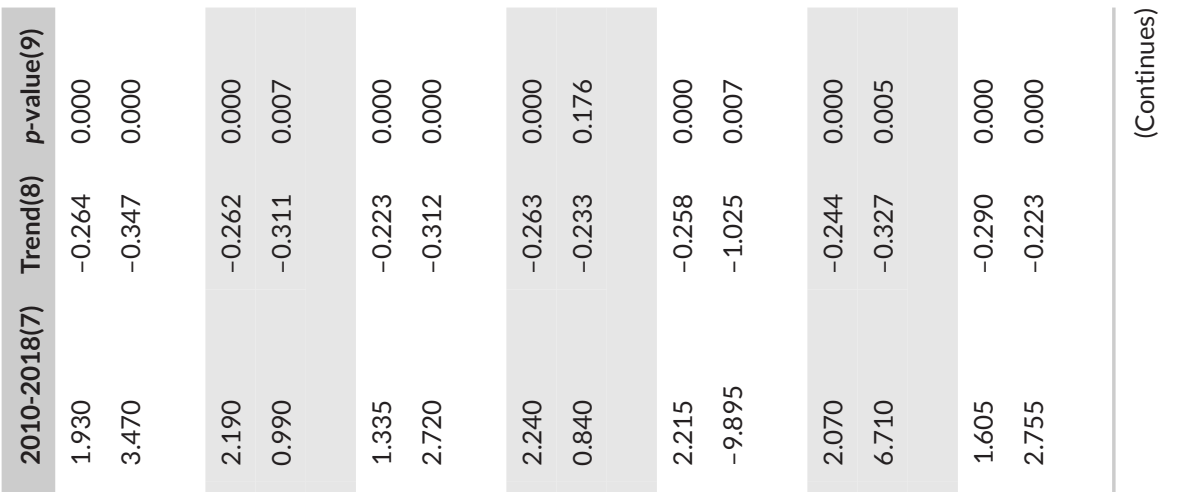

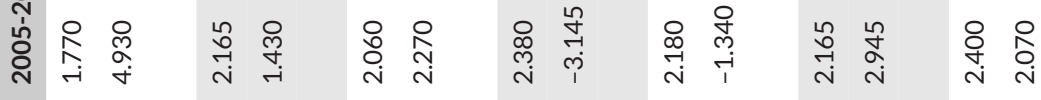

旁

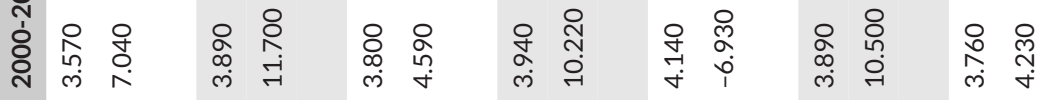

$\frac{\partial}{g}$

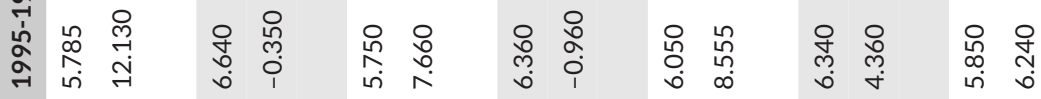

कू

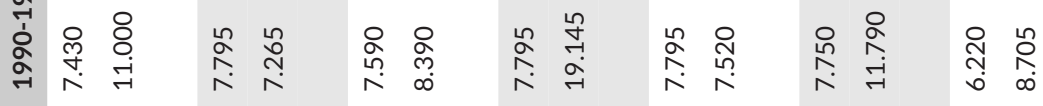

$\frac{9}{9}$

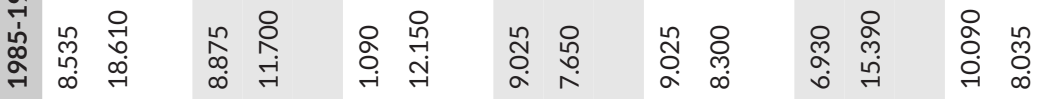

$\underset{\infty}{-1}$

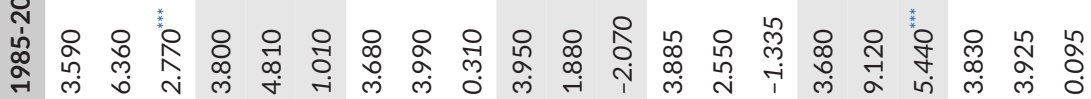

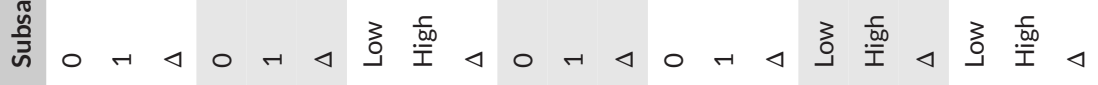
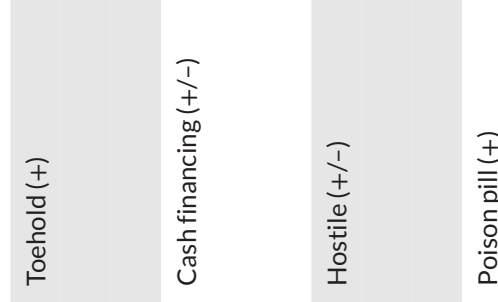


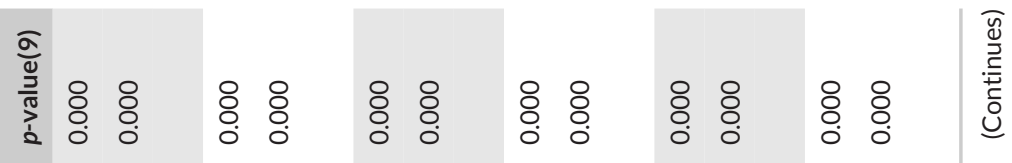

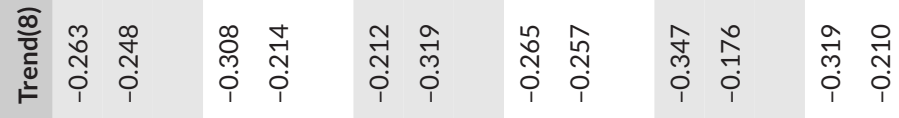

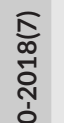

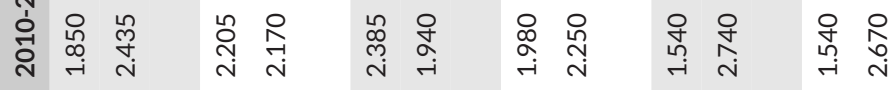
ㅇำ

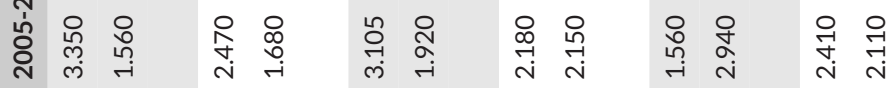
ণ্ণ

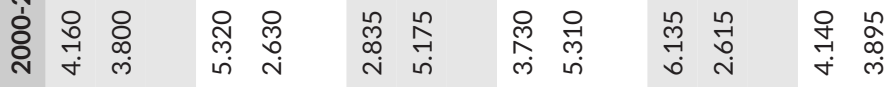

$\frac{d}{\frac{a}{g}}$

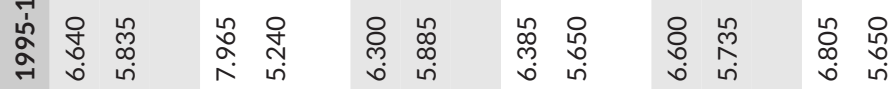

$\frac{\mathrm{m}}{\mathrm{g}}$

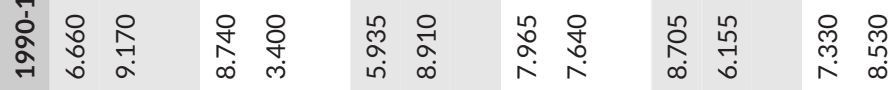

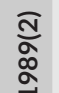

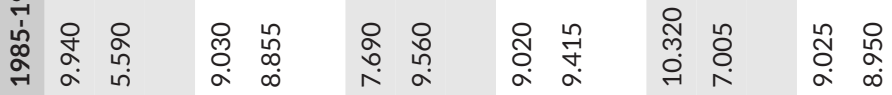

స్ำ

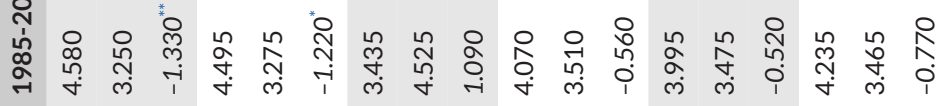

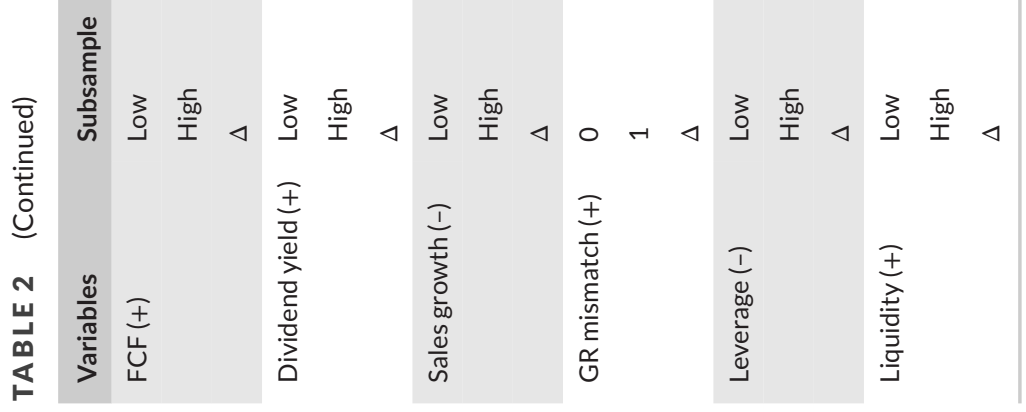




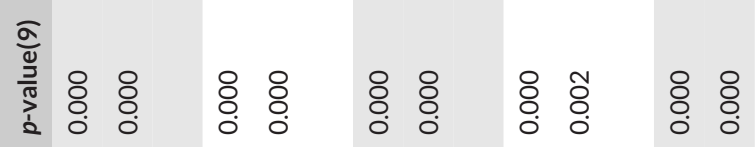

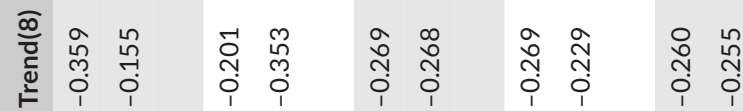

竞

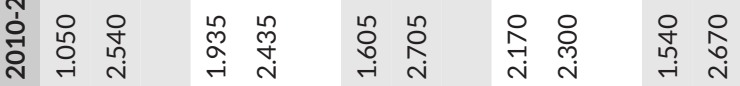

อั

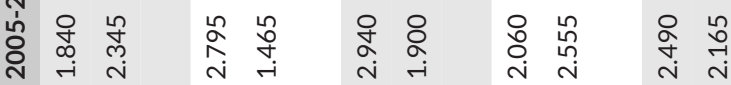

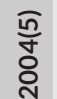

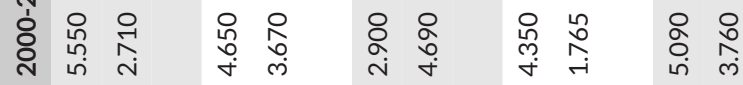

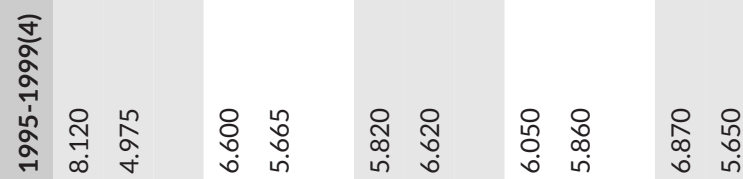

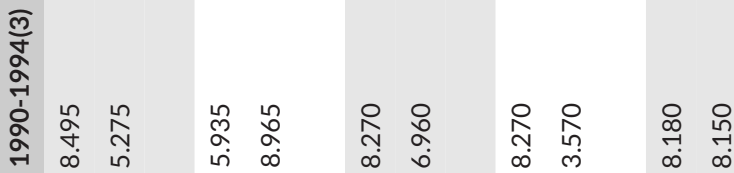

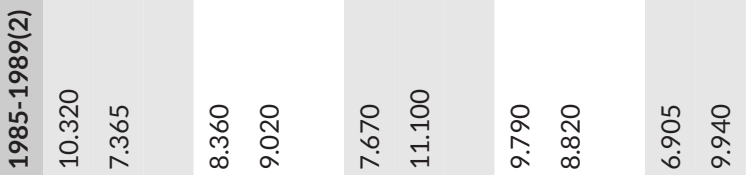

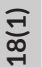

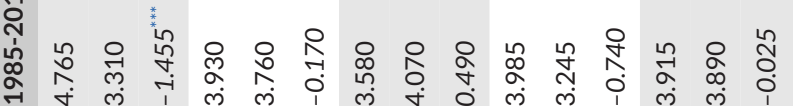

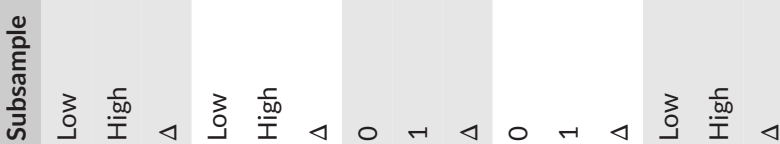

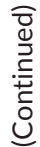

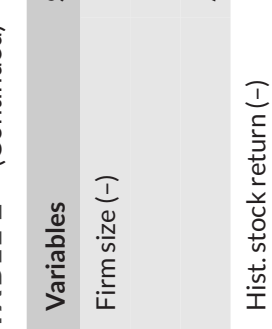

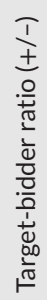

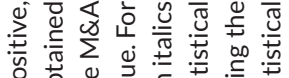

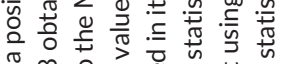

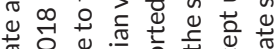

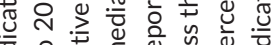
을

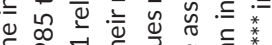

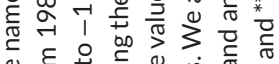

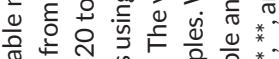

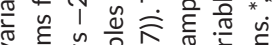

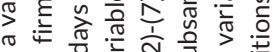

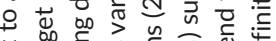

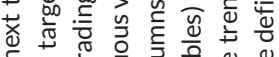

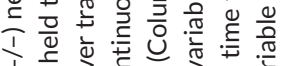

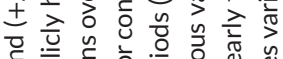

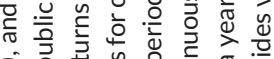

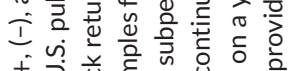

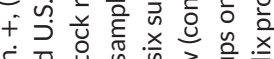

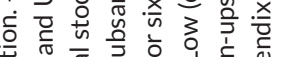

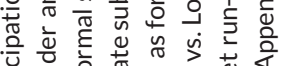
은

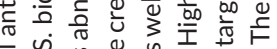
चٓ

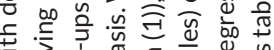

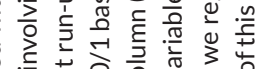

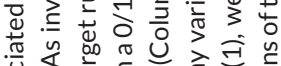
पू山

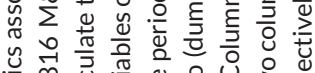

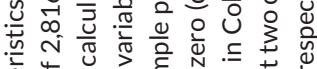

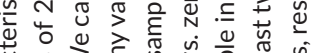

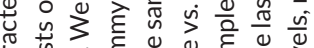

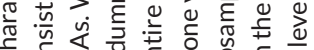

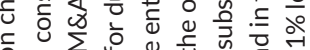
б पू山 है

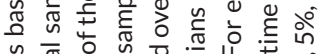

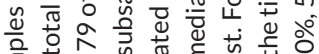
성

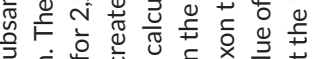

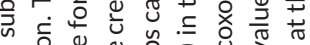

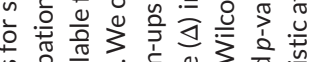

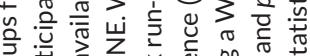

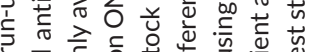
ত व

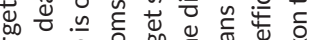

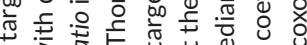

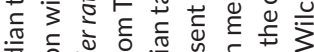

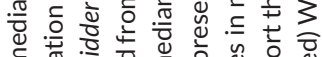

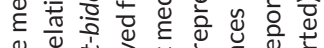

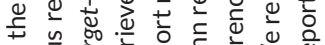

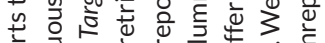
흥.

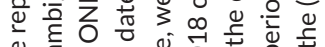
元 证 它

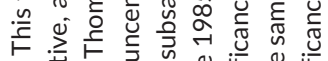

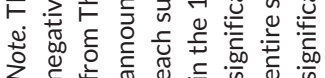


based on deal and firm characteristics. ${ }^{5}$ Superscripted asterisks indicate the significance of (unreported) Wilcoxon test statistics for the differences in the full period subsample medians. We expect larger target run-ups for deals that are more likely to be anticipated by investors. Consistent with this prediction, we find higher run-ups for deals with preannouncement information leakage as captured by a Rumor dummy variable equal to one. Also in line with this prediction, we obtain higher run-ups for deals with higher Number of bidders and lower run-ups for deals with a larger target Firm size. Inconsistent with our expectations, however, we find higher run-ups for deals with lower FCF and Dividend yield. We do not find significant differences in run-ups when splitting the sample according to the other deal and firm characteristics.

The main goal of this univariate analysis is to establish whether the significant time trend in run-ups persists across subsamples based on various characteristics associated with deal anticipation. In Columns (2)-(7), we report median target run-ups for subsamples based on characteristics in six subperiods within the overall sample period. Target runups tend to decline over time except for the subsample of Hostile deals for which the pattern in run-ups is less clear. As a more formal test, we regress the target run-ups on an annual Trend variable, defined as the announcement year of the deal minus 1985, the first year of the sample period, and an intercept for each of the individual subsamples. Columns (8) and (9) report a negative time trend (i.e., significant at less than 1\%) in target run-ups across each of the subsamples that we consider except for the subsample of Hostile deals. We note that only very few of the deals in our data set (i.e., 93 of 2,816) are marked as "hostile" in Thomson ONE. Empirically distinguishing hostile from nonhostile deals is problematic (Schwert, 2000), so we do not place much weight on the nonsignificance of Trend for this very small subset of deals. The magnitude of the Trend variable is typically higher (i.e., more negative) for those subsamples with a relatively high median target run-up in the early part of the sample period. Overall, we conclude that the decline in target run-ups over time seems robust across deals with different characteristics.

Next, we conduct an ordinary least squares (OLS) regression in which we regress target run-ups on the above characteristics associated with deal anticipation. Table 3 presents the regression results. Reported $t$-statistics of all regressions in the paper are based on robust standard errors. We follow a similar approach to Custódio, Ferreira, and Laureano (2013) in their analysis of the decline in corporate debt maturity. In a first model, reported in Column (1), we include deal anticipation proxies without time trend controls. Among the deal characteristics, Rumor has a significant impact with the predicted positive sign. For the target characteristics, we find a negative impact for Firm size, in line with our predictions. In addition, we find a negative impact of FCF, which is inconsistent with the argument that firms with higher free cash flows are more likely to be acquired as they may have run out of profitable growth opportunities. We also find a negative impact for Target-bidder ratio for which we have no clear expectations. The $R^{2}$ of the model is approximately $4 \%$, which is a similar order of magnitude as the $R^{2} s$ in the Brigida and Madura (2012) analysis of target run-ups.

In Column (2), we include five time period dummy variables. The dummies are constructed so that they show the incremental effect of a certain time period when compared to the period immediately prior. We find a significant reduction in target run-ups from the 1995-1999 period to the 2000-2004 period, and from the 2000-2004 period to the 2005-2009 period. This result suggests that changes in deal- and firm-specific deal anticipation proxies cannot fully account for the decline in target run-ups. With regard to the deal anticipation proxies, we now find a significant impact for Cash financing that was insignificant in the previous model. The positive sign of its coefficient is consistent with the conjecture that cash deals are more anticipated. The results for the other proxies remain largely similar to those in Column (1). The model in Column (3) replicates the previous model including year dummy variables instead of interval dummies. The year dummy variables take a value of one if the deal was announced that year and are zero otherwise. There are 33 year dummies in total starting in 1986 and ending in 2018. We do not report the coefficients of individual year dummy variables for parsimony. An F-test statistic for the significance of the year dummy variables equals 4.63, strongly rejecting the null hypothesis that their coefficients are jointly equal to zero ( $p$-value $<0.001$ ).

\footnotetext{
${ }^{5}$ In unreported tests, we obtain similar results when focusing on averages.
} 
TAB LE 3 OLS Regression of target run-ups

\begin{tabular}{|c|c|c|c|c|c|c|}
\hline \multirow[b]{2}{*}{ Variables } & \multicolumn{5}{|c|}{ Deal anticipation } & \multirow{2}{*}{$\begin{array}{l}\text { Insider trading } \\
\text { (6) }\end{array}$} \\
\hline & (1) & (2) & (3) & (4) & (5) & \\
\hline \multirow[t]{2}{*}{ Trend } & & & & $-0.257^{* * *}$ & $-0.278^{* * *}$ & 0.082 \\
\hline & & & & $(-8.323)$ & $(-8.538)$ & $(0.691)$ \\
\hline \multirow[t]{2}{*}{ Rumor } & $4.709^{* * *}$ & $4.804^{* * *}$ & $4.633^{* * *}$ & & $4.803^{* * *}$ & $4.765^{* * *}$ \\
\hline & $(5.530)$ & $(5.748)$ & $(5.585)$ & & $(5.765)$ & $(5.732)$ \\
\hline \multirow[t]{2}{*}{ Toehold } & 0.280 & -1.030 & -0.847 & & -0.968 & -0.886 \\
\hline & $(0.205)$ & $(-0.757)$ & $(-0.609)$ & & $(-0.723)$ & $(-0.652)$ \\
\hline \multirow[t]{2}{*}{ Cash financing } & 0.003 & $0.017^{* *}$ & $0.018^{* *}$ & & $0.013^{*}$ & $0.018^{* *}$ \\
\hline & $(0.497)$ & (2.396) & $(2.461)$ & & $(1.942)$ & $(2.500)$ \\
\hline \multirow[t]{2}{*}{ Hostile } & -1.195 & -0.445 & -0.896 & & -0.200 & -0.447 \\
\hline & $(-0.620)$ & $(-0.238)$ & $(-0.477)$ & & $(-0.106)$ & $(-0.238)$ \\
\hline \multirow[t]{2}{*}{ Poison pill } & 1.581 & -0.712 & -0.444 & & -1.203 & -0.826 \\
\hline & $(0.475)$ & $(-0.214)$ & $(-0.134)$ & & $(-0.364)$ & $(-0.240)$ \\
\hline \multirow[t]{2}{*}{ Number of bidders } & 1.474 & 0.320 & 0.553 & & 0.197 & 0.313 \\
\hline & (1.488) & $(0.328)$ & $(0.580)$ & & $(0.203)$ & $(0.322)$ \\
\hline \multirow[t]{2}{*}{ Market-to-book } & -0.076 & -0.020 & -0.097 & & -0.005 & -0.073 \\
\hline & $(-0.429)$ & $(-0.115)$ & $(-0.544)$ & & $(-0.031)$ & $(-0.415)$ \\
\hline \multirow[t]{2}{*}{ FCF } & $-5.446^{*}$ & $-5.890^{* *}$ & $-5.666^{* *}$ & & $-5.889^{* *}$ & $-5.773^{* *}$ \\
\hline & $(-1.921)$ & $(-2.125)$ & $(-2.005)$ & & $(-2.109)$ & $(-2.093)$ \\
\hline \multirow[t]{2}{*}{ Dividend yield } & -4.529 & -10.053 & -8.615 & & -11.626 & -9.229 \\
\hline & $(-0.282)$ & $(-0.625)$ & $(-0.541)$ & & $(-0.722)$ & $(-0.576)$ \\
\hline \multirow[t]{2}{*}{ Sales growth } & 0.009 & -0.004 & -0.010 & & -0.004 & -0.009 \\
\hline & $(0.560)$ & $(-0.253)$ & $(-0.615)$ & & $(-0.228)$ & $(-0.549)$ \\
\hline \multirow[t]{2}{*}{ GR mismatch } & -0.122 & 0.157 & 0.136 & & 0.130 & 0.283 \\
\hline & $(-0.166)$ & $(0.216)$ & (0.188) & & (0.179) & (0.390) \\
\hline \multirow[t]{2}{*}{ Leverage } & -0.049 & 0.057 & 0.205 & & -0.004 & 0.196 \\
\hline & $(-0.127)$ & $(0.147)$ & $(0.531)$ & & $(-0.010)$ & $(0.507)$ \\
\hline \multirow[t]{2}{*}{ Liquidity } & -0.073 & 0.753 & 0.729 & & 0.332 & 0.833 \\
\hline & $(-0.063)$ & $(0.654)$ & $(0.622)$ & & $(0.290)$ & $(0.723)$ \\
\hline \multirow[t]{2}{*}{ Firm size } & $-1.020^{* * *}$ & $-0.666^{* * *}$ & $-0.641^{* * *}$ & & $-0.703^{* * *}$ & $-0.643^{* * *}$ \\
\hline & $(-4.970)$ & $(-3.201)$ & $(-3.064)$ & & $(-3.399)$ & $(-3.083)$ \\
\hline \multirow[t]{2}{*}{ Historical stock return } & -3.959 & -3.204 & 1.780 & & -4.471 & -0.323 \\
\hline & $(-1.032)$ & $(-0.822)$ & $(0.416)$ & & $(-1.180)$ & $(-0.081)$ \\
\hline \multirow[t]{2}{*}{ State } & -0.163 & 0.118 & 0.090 & & 0.170 & 0.155 \\
\hline & $(-0.283)$ & $(0.207)$ & $(0.157)$ & & $(0.298)$ & $(0.272)$ \\
\hline \multirow[t]{2}{*}{ Private bidder } & 0.572 & 1.049 & 1.225 & & 0.736 & 0.933 \\
\hline & $(0.394)$ & (0.719) & (0.811) & & (0.509) & $(0.638)$ \\
\hline
\end{tabular}


TABLE 3 (Continued)

\begin{tabular}{|c|c|c|c|c|c|c|}
\hline \multirow[b]{2}{*}{ Variables } & \multicolumn{5}{|c|}{ Deal anticipation } & \multirow{2}{*}{$\begin{array}{l}\text { Insider trading } \\
\text { (6) }\end{array}$} \\
\hline & (1) & (2) & (3) & (4) & (5) & \\
\hline \multirow[t]{2}{*}{ Target-bidder ratio } & $-0.572^{* *}$ & $-0.673^{* * *}$ & $-0.655^{* * *}$ & & $-0.629^{* * *}$ & $-0.676^{* * *}$ \\
\hline & $(-2.514)$ & $(-3.002)$ & $(-2.915)$ & & $(-2.799)$ & $(-3.023)$ \\
\hline \multirow[t]{2}{*}{ 1990-1994 } & & -0.487 & & & & \\
\hline & & $(-0.291)$ & & & & \\
\hline \multirow[t]{2}{*}{ 1995-1999 } & & -0.558 & & & & \\
\hline & & $(-0.432)$ & & & & \\
\hline \multirow[t]{2}{*}{ 2000-2004 } & & $-2.512^{* * *}$ & & & & \\
\hline & & $(-2.914)$ & & & & \\
\hline \multirow[t]{2}{*}{ 2005-2009 } & & $-2.751^{* * *}$ & & & & \\
\hline & & $(-3.102)$ & & & & \\
\hline \multirow[t]{2}{*}{ 2010-2018 } & & -0.183 & & & & \\
\hline & & $(-0.244)$ & & & & \\
\hline \multirow[t]{2}{*}{ IT event $1(11 / 19 / 1988)$} & & & & & & -1.878 \\
\hline & & & & & & $(-0.993)$ \\
\hline \multirow[t]{2}{*}{ IT event $2(10 / 23 / 2000)$} & & & & & & $-3.254^{* * *}$ \\
\hline & & & & & & $(-2.622)$ \\
\hline \multirow[t]{2}{*}{ IT event $3(08 / 14 / 2003)$} & & & & & & $-2.933^{* * *}$ \\
\hline & & & & & & $(-2.606)$ \\
\hline \multirow[t]{2}{*}{ IT event 4 (01/27/2009) } & & & & & & -0.883 \\
\hline & & & & & & $(-0.718)$ \\
\hline \multirow[t]{2}{*}{ Constant } & $12.072^{* * *}$ & $14.312^{* * *}$ & $16.887^{* * *}$ & $10.823^{* * *}$ & $16.116^{* * *}$ & $14.168^{* * *}$ \\
\hline & (6.050) & (5.893) & (5.084) & $(16.227)$ & (7.924) & (5.611) \\
\hline$R^{2}$ & 0.032 & 0.064 & 0.088 & 0.027 & 0.059 & 0.069 \\
\hline Year fixed effects & No & No & Yes & No & No & No \\
\hline$N$ & 2,279 & 2,279 & 2,279 & 2,279 & 2,279 & 2,279 \\
\hline
\end{tabular}

Note. This table reports the estimates of the OLS regressions of target run-ups on deal- and firm-specific explanatory variables. The sample consists of 2,279 M\&As involving U.S. bidder and target firms from 1985-2018 obtained from Thomson ONE. We calculate target run-ups as abnormal stock returns over trading days -20 to -1 relative to the M\&A announcement date retrieved from Thomson ONE. The Appendix provides the variable definitions. $t$-statistics, based on robust standard errors, are in parentheses. *, ** and ${ }^{* * *}$ indicate statistical significance at the $10 \%, 5 \%$, and $1 \%$ levels, respectively. $N$ denotes the number of observations.

In the remaining analyses, we work with a Trend variable instead of interval dummies, as a time trend variable makes it easier to quantify the magnitude of the annual decrease in target run-ups. In Column (4), we run a baseline regression in which we only include an annual time trend and an intercept. We find a significant decrease in target run-ups of $-0.26 \%$ per year. In Column (5), we test whether this time trend persists when controlling for deal- and firm-specific deal anticipation proxies. We find that this is the case. The coefficient of the Trend variable $(-0.28 \%)$ remains negative and significant.

In unreported tests, we include several other control variables. Ambrose and Megginson (1992) find a higher takeover probability for firms with a higher percentage of tangible assets that may be due to these firms having more debt capacity or fewer growth opportunities. Our findings remain unaltered when controlling for the target firms' 
tangible assets. Our results also remain similar when we control for fluctuations in interest rates to capture the opportunity cost investors face when purchasing target shares before predicted merger announcements, as well as for annual volumes of $M \& A$ deals to capture increased takeover activity over time and for industry fixed effects.

On the whole, the univariate analyses in Table 2 and the regression results in Columns (2)-(5) of Table 3 suggest that the decline in target run-ups does not seem fully attributable to the changes in deal and firm characteristics associated with deal anticipation. However, these tests cannot completely rule out a deal anticipation explanation of the decline in run-ups for the following two reasons. First, even with deal and firm characteristics remaining constant, it may have become less straightforward for investors to predict upcoming $M \& A$ targets. M\&A motives change over time (Bruner, 2004), which could make traditional target prediction models less capable of identifying targets. Of course, market participants nowadays have a wealth of information and sophisticated prediction tools at their fingertips, but it could still be more difficult for them to weed out relevant pieces of information and accurately predict target firms. If investors refrain from preannouncement buying of target stocks when their predictors get noisier, we would see a decline in run-ups over time even after controlling for traditional deal anticipation proxies. In addition, even with constant deal anticipation proxies and unchanged investor ability to predict target firms, there could be a reduced likelihood in the probability of deal completion for more recent M\&As. This could result in lower preannouncement target run-ups (Betton et al., 2014). Several of the deal anticipation proxies in our model can also act as proxies for the likelihood of deal completion. For example, Hostile deals are typically less likely to complete and merger payment, as captured in Cash financing, could also affect the probability of deal completion (Baker \& Savaşoglu, 2002). For completeness, we reestimate Column (5) of Table 3 including a deal completion probability, estimated from a logistic model for deal completion derived from Baker and Savaşoglu (2002), as an additional explanatory variable. Our conclusions remain unaltered suggesting that changes in predicted deal completion likelihood do not drive the results. ${ }^{6}$

In sum, while we cannot completely eliminate a deal anticipation explanation for the decline in target run-ups, we do not obtain empirical results consistent with this explanation. In the next subsection, we explore the insider trading hypothesis as an alternative explanation.

\section{2 | Insider trading hypothesis}

The insider trading hypothesis argues that target run-ups result from illegal trading activity by corporate insiders. It is very hard, even with sophisticated econometric models, to empirically disentangle illegal trading from legal trading by informed traders (Minenna, 2003). However, our long sample window enables us to exploit changes in U.S. insider trading regulations over the past decades. U.S. insider trading rules have become increasingly stringent over time. Under the insider trading hypothesis, the decrease in target run-ups could be attributed to enhanced insider trading regulations as traders increasingly fear detection and punishment. Based on a literature search, we identify four important potential increases in the strength of insider trading rules and their enforcement over our sample period. We start our search after 1985 as we do not have sufficient sample observations prior to that year.

A first important change in regulation occurred in 1988 with the Insider Trading and Securities Fraud Enforcement Act (Seitzinger, 2016). The Act, effective from November 19, 1988, expanded the scope of civil penalties for persons failing to take adequate steps to prevent insider trading. It specified that investors suffering financial losses due to the misuse of nonpublic information have the right to take legal action against insider traders, and explained that both the leaker of inside information and the recipient of this information can be penalized. The next large regulatory change, effective from October 23, 2000, was the Selective Disclosure and Insider Trading Rules including Regulation Fair

\footnotetext{
${ }^{6}$ Since our baseline sample only includes completed deals, we use an extended sample that includes 2,274 deals identified as "Withdrawn" in Thomson ONE to estimate the deal completion probability. It is worth noting that the percentage of withdrawn deals (out of the total number of announced M\&A deals) has not increased over time.
} 
Disclosure (Reg FD). ${ }^{7}$ This regulation states that when an issuer or representative reveals nonpublic information to third parties, such as analysts or shareholders, the information must simultaneously be disclosed publicly. Gintschel and Markov (2004) document Reg FD's effectiveness in reducing the incremental information in analysts' information output. A third important change to the regulation was the Sarbanes-Oxley (SOX) Act effective from August 14,2003 . While SOX was not primarily intended to reduce illegal information leaks, it may have indirectly had this effect by requiring executives to be more accountable for the information disclosed by their firms (Brigida \& Madura, 2012). The SOX Act also increased penalties associated with insider trading. The fourth important change related to the enforceability of insider trading regulation, which increased substantially after the appointment of Mary Schapiro as SEC Chairwoman on January 27, 2009. More particularly, her appointment led to a strong upsurge in investigations, including the Galleon insider trading case later that year, resulting in the arrest and sentencing of hedge fund manager Raj Rajaratnam. ${ }^{8}$

Figure 2 reports graphs in which we analyze median target run-ups only for those deals announced in 180-trading day windows before and after the enactment of each event associated with a strengthening of insider trading rules or the enforcement of those rules. We henceforth label these events "insider trading (IT) events." We leave a 90-trading day gap after each IT event so that the run-ups of postevent deals do not include pre-event trading days. We calculate abnormal stock returns in the same way as our main run-up measure using 20-day abnormal stock returns obtained through market model regressions ending on the trading day prior to the deal announcement. The median 20-day preannouncement target run-up for deals announced during the 180-day period prior to the first IT event (November 19,1988 ) is $11.61 \%$. The median target run-up falls to $8.36 \%$ for deals announced in the period ranging from trading days 90 up to 270 after the enactment of that first regulation. Similarly, median target run-ups around the second IT event (October 23, 2000) declined from 5.81\% for deals announced in the 180 days before to $4.49 \%$ for deals announced in the 180 days after the enactment of the regulation. Following the third IT event (August 14, 2003), median run-ups declined from $3.71 \%$ to $1.52 \%$. The fourth graph illustrates a very high median run-up prior to the January 27,2009 , IT event (9.43\%) dropping down to $0.90 \%$ after the event. Median run-ups on a yearly basis (not shown for parsimony) confirm that target run-ups tend to be abnormally high in the year 2009. One potential explanation is that the Global Financial Crisis may have led to stronger insider trading on private knowledge about upcoming M\&A deals in an attempt to compensate for losses occurring on other (legal) trades during that period.

Together, these graphs suggest that events associated with more stringent insider trading rules tend to be associated with declines in target run-ups. To examine this conjecture more formally, we reestimate the model in Column (5) of Table 3, adding dummy variables capturing each of the four IT events. Each IT event dummy variable has a value of zero before the relevant event and one afterward. Accordingly, the coefficients on the dummy variables represent the change in run-ups relative to the prior period. Table 3, Column (6) reports the findings. All four dummy variables obtain a negative coefficient in line with target run-ups being lower after the IT events. The reduction is statistically significant for IT event 2 and IT event 3 corresponding to Reg FD and SOX, respectively. Most importantly, the time trend coefficient is no longer statistically significant following the introduction of the IT event dummies. In other words, no time trend in target run-ups remains in the periods in between the regulation changes. Thus, our results are in line with insider trading regulation as an explanation for the decline in target run-ups. The findings regarding the impact of deal anticipation proxies on run-ups remain similar to those in previous columns.

In a further test, we quantify the component of the run-ups that is not attributable to changes in deal- and firmspecific characteristics. This analysis serves to obtain better insight into the magnitude of the target run-up decline unexplained by deal anticipation proxies. In line with Custódio et al. (2013), we first estimate the regression in Table 3, Column (1), over a window ranging from January 1, 1985 (the start of our research period), until October 22, 2000.

\footnotetext{
${ }^{7}$ We focus on the dates on which the regulations became effective, rather than when they were announced, as the former dates should be most relevant for insider traders.

${ }^{8}$ We obtain the insider trading reducing events by compiling information from the following academic and business sources: Newkirk and Robertson (1998), Steinberg (2003), Hohenstein (2006), Thompson (2013), Ventoruzzo (2015), Seitzinger (2016), and Del Guercio, Odders-White, and Ready (2017).
} 


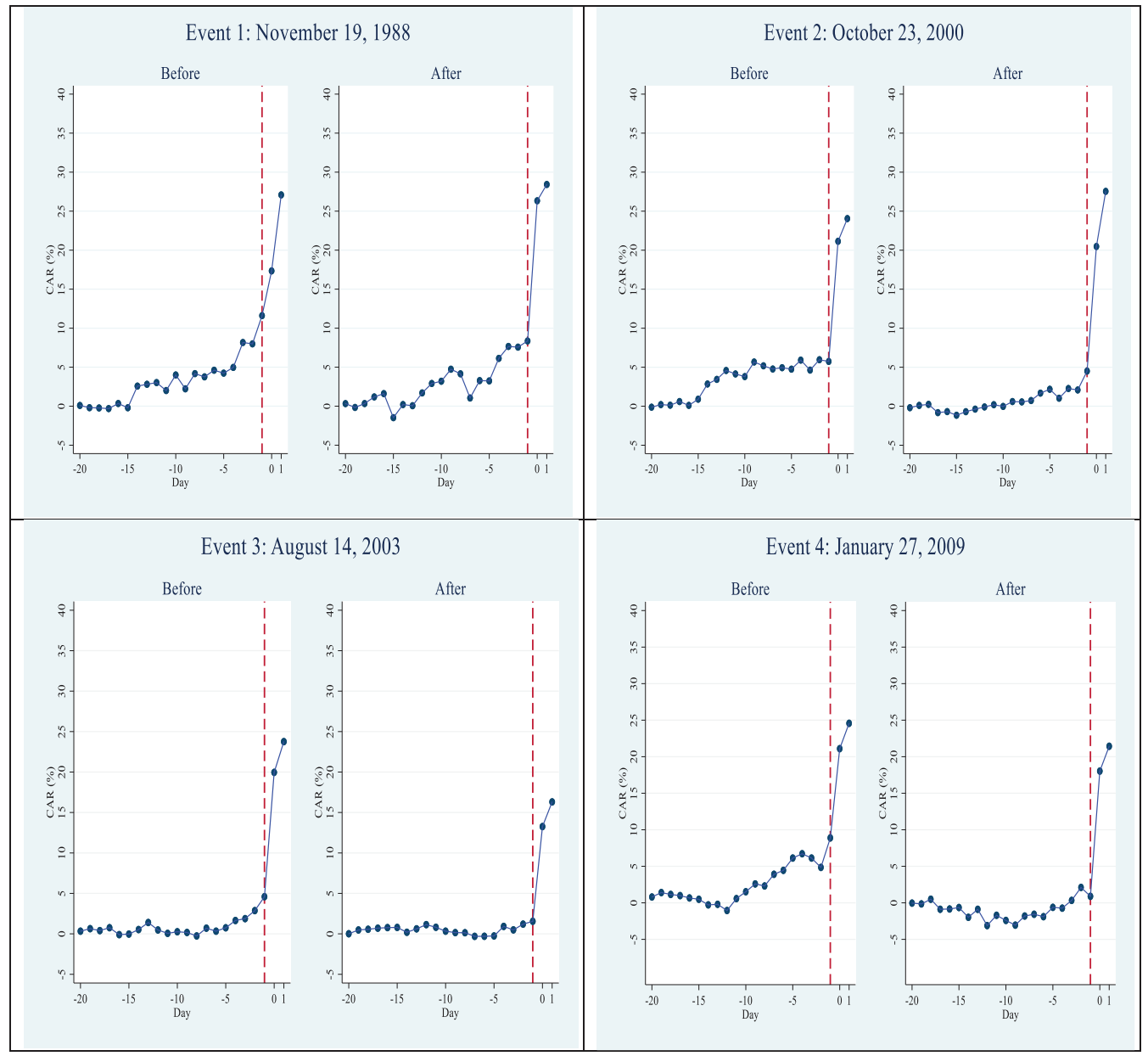

FIGURE 2 Median target stock run-ups for deals immediately before and after insider trading reducing events [Color figure can be viewed at wileyonlinelibrary.com]

Note. This figure reports the median target stock run-ups for M\&A deals announced before and after the enactment of four events associated with more stringent insider trading rules in the United States. The sample consists of 2,816 M\&As involving U.S. bidder and target firms from 1985 to 2018 obtained from Thomson ONE. We leave a 90 trading day gap after each event so that the run-up period for postevent deals does not include preevent trading days. Days represent trading days relative to the M\&A announcement date are retrieved from Thomson ONE. The vertical line highlights day -1 . Abnormal stock returns are estimated with market model regressions. We estimate these regressions over a period of 190 days ending on day -76 relative to the announcement date. We use the CRSP equally weighted index as a proxy for the market portfolio.

We stop right before October 23, 2000 as this day coincides with the first IT event with a significant impact in Table 3, and we want to use an estimation period that is relatively clean of key changes in insider trading rules. ${ }^{9}$ The results of this regression are highly similar to those for the full sample in Table 3, Column (1). We use the coefficients of this regression to predict the run-ups for a holdout sample consisting of the remaining deals taking place from October 23,2000 , until the end of 2018. We then compute how actual run-ups over the period 2000-2018 differ from those

\footnotetext{
${ }^{9}$ Restricting the estimation period from 1985 to the trading day before the enactment of the first IT event in 1988 substantially reduces the size of the sample that can be used (to 99 observations), but leads to qualitatively similar results.
} 
TAB LE 4 Predicted run-up and deviations from actual run-up by year

\begin{tabular}{|c|c|c|c|c|c|}
\hline Year & Actual & Predicted & Actual-Predicted & $t$-statistic & $N$ \\
\hline 2001 & 4.899 & 9.368 & -4.470 & $-3.387^{* * *}$ & 113 \\
\hline 2002 & 5.787 & 9.949 & -4.162 & $-2.275^{* *}$ & 55 \\
\hline 2003 & 4.673 & 9.707 & -5.033 & $-4.088^{* * *}$ & 99 \\
\hline 2004 & 4.222 & 9.416 & -5.194 & $-5.212^{* * * *}$ & 99 \\
\hline 2005 & 3.136 & 9.592 & -6.456 & $-6.473^{* * *}$ & 81 \\
\hline 2006 & 3.915 & 9.123 & -5.209 & $-4.993^{* * *}$ & 89 \\
\hline 2007 & 1.867 & 9.512 & -7.645 & $-7.286^{* * *}$ & 93 \\
\hline 2008 & 8.300 & 10.015 & -1.715 & -0.713 & 47 \\
\hline 2009 & 4.379 & 8.653 & -4.275 & $-2.185^{* *}$ & 51 \\
\hline 2010 & 4.396 & 10.322 & -5.926 & $-3.388^{* * * *}$ & 63 \\
\hline 2011 & 4.629 & 9.295 & -4.666 & $-2.777^{* * *}$ & 47 \\
\hline 2012 & 3.336 & 10.559 & -7.224 & $-5.493^{* * *}$ & 58 \\
\hline 2013 & 1.573 & 9.104 & -7.531 & $-8.108^{* * *}$ & 65 \\
\hline 2014 & 2.522 & 9.604 & -7.083 & $-6.051^{* * *}$ & 67 \\
\hline 2015 & 6.963 & 9.253 & -2.289 & $-1.783^{*}$ & 80 \\
\hline 2016 & 2.197 & 9.336 & -7.139 & $-5.467^{* * *}$ & 63 \\
\hline 2017 & 3.319 & 8.764 & -5.446 & $-4.038^{* * *}$ & 55 \\
\hline 2018 & 3.345 & 8.126 & -4.781 & $-4.447^{* * *}$ & 70 \\
\hline
\end{tabular}

Note. This table reports the differences between the actual and the predicted average target run-ups. We calculate target run-ups as abnormal stock returns over trading days -20 to -1 relative to the $M \& A$ announcement date retrieved from Thomson ONE. Predicted values are obtained using the coefficients of the explanatory variables for the sample period from 01/01/1985-10/22/2000. The total sample consists of 2,279 M\&As involving U.S. bidder target firms from 1985-2018 obtained from Thomson ONE. The Appendix provides the variable definitions. $t$-statistics are for the differences between the actual and predicted average target run-ups. *, **, and ${ }^{* * *}$ indicate statistical significance at the $10 \%, 5 \%$, and $1 \%$ levels, respectively. $\mathrm{N}$ denotes the number of observations.

predicted by the model. The difference between actual and predicted run-ups measures the change in run-ups that cannot be attributed to changes in the deal and target characteristics. As reported in Table 4, predicted average runups are higher than actual run-ups in all years. Except for 2008 and 2015, the difference is always statistically significant at the $5 \%$ level or lower. The results are similar when we calculate median run-ups instead. The predicted run-ups do not decrease over time suggesting that changes in deal- and firm-related determinants cannot account for the decline in actual target run-ups.

\section{5 | ADDITIONAL EVIDENCE}

The relation between changes in insider trading regulation and changes in target run-ups could be spurious. This section provides additional tests that link U.S. insider trading regulations to U.S. target run-ups.

Table 5 provides more evidence regarding the relation between insider trading regulation and target run-ups by zooming in on a limited set of deals made either shortly before or after an IT event. The setup is similar to the analysis reported in Figure 2 that also restricted the analysis to M\&A deals announced in narrow windows before and after the enactment of the four IT events. The key independent variable of interest, IT event, is equal to one for deals announced in the window $[+90,+270]$ following one of the four IT events and zero for deals announced in the 180 trading days 
TAB LE 5 OLS regression of target run-ups in narrow windows around IT events

\begin{tabular}{|c|c|c|c|}
\hline Variables & (1) & (2) & (3) \\
\hline \multirow[t]{2}{*}{ IT event } & $-2.661^{*}$ & 6.234 & 5.454 \\
\hline & $(-1.664)$ & (1.274) & (1.092) \\
\hline \multirow[t]{2}{*}{ Number of target advisors } & 1.316 & $5.687^{* *}$ & $5.856^{*}$ \\
\hline & $(0.656)$ & $(1.996)$ & $(1.827)$ \\
\hline \multirow[t]{2}{*}{ IT event $\times$ Number of target advisors } & & $-7.463^{*}$ & $-6.759^{*}$ \\
\hline & & $(-1.901)$ & $(-1.689)$ \\
\hline \multirow[t]{2}{*}{ Rumor } & & & $6.257^{* *}$ \\
\hline & & & $(2.453)$ \\
\hline \multirow[t]{2}{*}{ Toehold } & & & 3.992 \\
\hline & & & $(1.075)$ \\
\hline \multirow[t]{2}{*}{ Cash financing } & & & 0.016 \\
\hline & & & (0.768) \\
\hline \multirow[t]{2}{*}{ Hostile } & & & $-16.579^{* *}$ \\
\hline & & & $(-2.132)$ \\
\hline \multirow[t]{2}{*}{ Poison pill } & & & 8.458 \\
\hline & & & (0.838) \\
\hline \multirow[t]{2}{*}{ Number of bidders } & & & 2.311 \\
\hline & & & $(0.817)$ \\
\hline \multirow[t]{2}{*}{ Market-to-book } & & & -0.748 \\
\hline & & & $(-1.434)$ \\
\hline \multirow[t]{2}{*}{ FCF } & & & $-20.755^{* *}$ \\
\hline & & & $(-2.336)$ \\
\hline \multirow[t]{2}{*}{ Dividend yield } & & & -26.025 \\
\hline & & & $(-0.550)$ \\
\hline \multirow[t]{2}{*}{ Sales growth } & & & 0.001 \\
\hline & & & (0.019) \\
\hline \multirow[t]{2}{*}{ GR mismatch } & & & -0.850 \\
\hline & & & $(-0.416)$ \\
\hline \multirow[t]{2}{*}{ Leverage } & & & 0.590 \\
\hline & & & $(0.495)$ \\
\hline \multirow[t]{2}{*}{ Liquidity } & & & 3.805 \\
\hline & & & $(1.180)$ \\
\hline \multirow[t]{2}{*}{ Firm size } & & & $-1.085^{*}$ \\
\hline & & & $(-1.735)$ \\
\hline \multirow[t]{2}{*}{ Historical stock return } & & & 9.931 \\
\hline & & & $(0.871)$ \\
\hline \multirow[t]{2}{*}{ State } & & & 0.024 \\
\hline & & & $(0.015)$ \\
\hline
\end{tabular}


TABLE 5 (Continued)

\begin{tabular}{llll}
\hline Variables & $(1)$ & $(2)$ & $(3)$ \\
\hline Private bidder & & & 1.115 \\
& & $0.282)$ \\
\hline Target-bidder ratio & & $-2.264^{* * *}$ \\
& & & $(-3.187)$ \\
\hline Constant & $14.200^{* * *}$ & $9.461^{* *}$ & $18.442^{* *}$ \\
& $(4.291)$ & $(2.390)$ & $(2.527)$ \\
\hline$R^{2}$ & 0.053 & 0.067 & 0.216 \\
\hline IT event fixed effects & Yes & Yes & Yes \\
\hline$N$ & 306 & 306 & 306 \\
\hline
\end{tabular}

Note. This table reports the estimates of the OLS regressions of target run-ups for M\&A deals announced in narrow windows before and after the enactment of four events associated with more stringent insider trading rules in the U.S. (IT events). These deals are retrieved from a larger sample consisting of M\&As involving U.S. bidder and target firms from 1985 to 2018 obtained from Thomson ONE. We calculate target run-ups as abnormal stock returns over trading days -20 to -1 relative to the M\&A announcement date retrieved from Thomson ONE. The key variable of interest, IT event, is equal to one for deals announced in the window $[+90,+270]$ following one of the four IT events, and zero for deals announced in the 180 trading days before one of the IT events. Other independent variables are explained in the Appendix. $t$-statistics, based on robust standard errors, are in parentheses. ${ }^{* * *}$, and ${ }^{* * *}$ indicate statistical significance at the $10 \%, 5 \%$, and $1 \%$ levels, respectively. $N$ denotes the number of observations.

preceding one of the IT events. In total, the analysis includes 306 deals. We perform an OLS regression analysis and include IT event fixed effects to examine post- to preregulation changes in target run-ups for a given regulation (i.e., to verify how the IT event dummy variable affects target run-ups while keeping the overall level of the run-ups around the regulations fixed). In Column (1), the IT event dummy variable has a negative coefficient. This suggests that declines in target run-ups are indeed associated with insider trading reducing events corroborating the graphical evidence in Figure 2.

The regression analysis allows us to further link IT events to target run-ups by exploiting cross-sectional differences in the probability of insider trading. If the reduction in target run-ups is indeed caused by reduced insider trading due to stricter regulations, the effect of insider trading regulation should be more pronounced for takeover targets that are more susceptible to insider information leakage. As Dai et al. (2017) argue, information leakage should be positively associated with the number of external parties involved in the deal. Following these authors, we use the number of financial advisors of the target firm (Number of target advisors) to capture cross-sectional differences in the probability of insider trading across target firms. In Column (2), we interact this measure with the IT event dummy variable. The coefficient on the interaction term is negative, consistent with the expectation that IT events should have a stronger effect on run-ups for targets more prone to be affected by insider trading. ${ }^{10}$ Column (3) indicates that this result holds while including deal- and firm-specific variables used in the baseline regression. Because these results are hard to explain by omitted variables unrelated to insider trading, they again suggest that declines in target run-ups link to IT events.

Brennan et al. (2018) find a strong increase in target shareholders' conditional probability of informed trading shortly before $M \& A$ announcements. The insider trading hypothesis suggests we should observe a reduction in target shareholders' probability of informed trading following events associated with increased insider trading regulation. An M\&A announcement should be good news for target shareholders, as it typically implies they will receive a takeover premium in the near future (Song \& Walkling, 2000). Thus, we focus on the probabilities of informed trading on good

\footnotetext{
10 We acknowledge that there is a strong correlation between Number of target advisors and deal size (Pearson's correlation of 0.29). However, the results in Table 5 continue to hold for subsamples split into large and small deals based on median deal size.
} 
news (PIN good) inferred from buying transactions. We obtain daily PIN good values for the period 1990-2014 from Brennan et al. (2018) who base their calculations on an earlier model of Easley, Kiefer, O'Hara, and Paperman (1996).

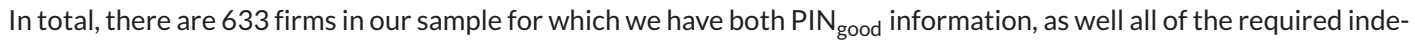
pendent variables available. Table 6 replicates the baseline analysis in Table 3 using average PIN good $_{\text {values calculated }}$ over trading days -20 to -1 relative to the announcement date, instead of target run-ups, as the dependent variable. Column (1) reports a decreasing trend in premerger PIN good consistent with our earlier findings for target run-ups. Column (2) adds deal and firm characteristics as explanatory variables. Most importantly, we find that the negative

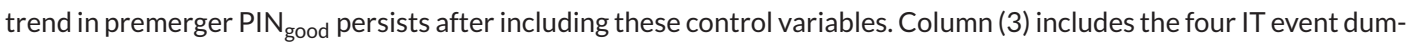
mies. Consistent with our baseline results based on target run-ups in Table 3, their inclusion renders the Trend variable insignificant. With respect to the individual IT event dummy variables, we find that IT event 3 and IT event 4 have a significant negative impact. Unlike the baseline results in Table 3, IT event 2 does not have a significant impact. We note, however, that the sample that can be used for the analysis in Table 6 is considerably smaller than that used for our baseline regressions (633 compared with 2,279 observations). We have particularly low coverage of deals in the early sample years that may account for the drop in significance for IT event 2. Overall, the target shareholders' PIN good analysis generates results consistent with our conjecture that target run-up declines are driven by a strengthening of insider trading regulation.

In a further additional test, we focus on the role of takeover premiums. Under the deal anticipation hypothesis, target run-ups reflect changes in the anticipated likelihood of a deal multiplied by the anticipated takeover premium (Betton et al., 2014; Schwert, 1996). The finding of declining run-ups may arise from a decrease in the magnitude of takeover premiums over time. This interpretation predicts a similar direction for any trend in target run-ups and announcement effects as both should be positively affected by the magnitude of the premium. In contrast with this prediction, as noted earlier, Table 1 notes an increasing trend in target announcement returns over the research period with target run-ups and target announcement returns having a significantly negative pairwise correlation ( -0.13$)$. To investigate the role of takeover premiums more formally, Table 7 reports the evolution of takeover premiums measured as the ratio of the offer price to the target's stock price one week before the announcement over the research period. The number of observations that we can use for this analysis (2,163 in total) is slightly lower than those in our main sample due to some missing takeover premium data in Thomson ONE. Consistent with a premium-related interpretation for the decline in target run-ups, we find a significant negative time trend in takeover premiums over the entire sample period. Average premiums are $42.97 \%$ in the $1985-1989$ interval, reach a minimum of $31.65 \%$ in the 2005-2009 interval, and then increase again to $32.83 \%$ in the final 2010-2018 subperiod. Median premiums exhibit a similar trend.

In a next step, we replicate the baseline target run-up regression analyses reported in Columns (5) and (6) of Table 3 with the takeover premium (Premium) as an additional control variable. We report the results of this augmented regression analysis in Columns (1) and (2) of Table 8. Most importantly, Column (1) indicates that the negative trend in target run-ups persists after controlling for Premium. Thus, the decrease in takeover premiums over our research period cannot explain the decline in target run-ups. Furthermore, similar to our baseline analysis, Column (2) reports that the significant time trend in target run-ups only disappears after controlling for IT events. Overall, our findings do not support that the decline in target run-ups arises from decreasing takeover premiums over time.

Also in Table 8, we replicate the baseline target run-up analysis without Target-bidder ratio as control variable. This allows us to use a larger sample of 2,816 M\&A deals since Target-bidder ratio is not available for most deals with privately held bidders. We find that the results are robust to using this larger sample.

Subsequently, we run a placebo test assessing the impact of U.S. IT events on Canadian M\&A target firms. These firms provide a suitable counterfactual for U.S. target firms due to important similarities in Canadian and U.S. institutional settings (de Bodt, Cousin, \& Roll, 2017; King, 2009) driven by a common legal ancestry (Buckley, 1997). However, insider trading rules and their enforcement are more lax in Canada when compared with U.S. rules (Bris, 2005). If the negative impact of the IT event dummy variables on U.S. target run-ups is indeed due to stronger insider trading mitigation in the United States, then we do not expect these dummy variables to be significant in a Canadian context. 
TAB LE 6 OLS regression of target shareholders' probability of informed trading on good news (PIN good $_{\text {) }}$

\begin{tabular}{|c|c|c|c|}
\hline Variables & (1) & (2) & (3) \\
\hline \multirow[t]{2}{*}{ Trend } & $-0.008^{* * *}$ & $-0.009^{* * *}$ & 0.004 \\
\hline & $(-6.214)$ & $(-5.662)$ & $(0.886)$ \\
\hline \multirow[t]{2}{*}{ Rumor } & & 0.025 & 0.024 \\
\hline & & (1.199) & (1.146) \\
\hline \multirow[t]{2}{*}{ Toehold } & & -0.043 & -0.018 \\
\hline & & $(-1.028)$ & $(-0.435)$ \\
\hline \multirow[t]{2}{*}{ Cash financing } & & -0.000 & -0.000 \\
\hline & & $(-0.699)$ & $(-1.160)$ \\
\hline \multirow[t]{2}{*}{ Hostile } & & -0.028 & -0.027 \\
\hline & & $(-0.484)$ & $(-0.487)$ \\
\hline \multirow[t]{2}{*}{ Poison pill } & & $0.193^{* * *}$ & $0.197^{* * *}$ \\
\hline & & (2.615) & $(2.760)$ \\
\hline \multirow[t]{2}{*}{ Number of bidders } & & -0.003 & -0.005 \\
\hline & & $(-0.072)$ & $(-0.136)$ \\
\hline \multirow[t]{2}{*}{ Market-to-book } & & $0.010^{* *}$ & 0.008 \\
\hline & & (2.031) & (1.619) \\
\hline \multirow[t]{2}{*}{ FCF } & & -0.038 & -0.019 \\
\hline & & $(-0.474)$ & $(-0.240)$ \\
\hline \multirow[t]{2}{*}{ Dividend yield } & & -0.400 & -0.226 \\
\hline & & $(-0.951)$ & $(-0.539)$ \\
\hline \multirow[t]{2}{*}{ Sales growth } & & $0.001^{*}$ & 0.001 \\
\hline & & $(1.822)$ & (1.377) \\
\hline \multirow[t]{2}{*}{ GR mismatch } & & -0.023 & -0.021 \\
\hline & & $(-1.159)$ & $(-1.081)$ \\
\hline \multirow[t]{2}{*}{ Leverage } & & $-0.023^{* *}$ & $-0.022^{* *}$ \\
\hline & & $(-2.108)$ & $(-2.090)$ \\
\hline \multirow[t]{2}{*}{ Liquidity } & & -0.047 & -0.037 \\
\hline & & $(-1.222)$ & $(-0.966)$ \\
\hline \multirow[t]{2}{*}{ Firm size } & & $0.034^{* * *}$ & $0.033^{* * *}$ \\
\hline & & (5.683) & $(5.722)$ \\
\hline \multirow[t]{2}{*}{ Historical stock return } & & -0.046 & 0.050 \\
\hline & & $(-0.383)$ & $(0.387)$ \\
\hline \multirow[t]{2}{*}{ State } & & 0.005 & 0.010 \\
\hline & & $(0.324)$ & $(0.611)$ \\
\hline \multirow[t]{2}{*}{ Private bidder } & & 0.055 & 0.053 \\
\hline & & (1.414) & (1.336) \\
\hline \multirow[t]{2}{*}{ Target-bidder ratio } & & -0.009 & -0.010 \\
\hline & & $(-1.416)$ & $(-1.468)$ \\
\hline
\end{tabular}


TABLE 6 (Continued)

\begin{tabular}{|c|c|c|c|}
\hline Variables & (1) & (2) & (3) \\
\hline \multirow[t]{2}{*}{ IT event $2(10 / 23 / 2000)$} & & & -0.027 \\
\hline & & & $(-0.799)$ \\
\hline \multirow[t]{2}{*}{ IT event 3 (08/14/2003) } & & & $-0.063^{*}$ \\
\hline & & & $(-1.762)$ \\
\hline \multirow[t]{2}{*}{ IT event $4(01 / 27 / 2009)$} & & & $-0.127^{* * *}$ \\
\hline & & & $(-3.402)$ \\
\hline \multirow[t]{2}{*}{ Constant } & $0.386^{* * *}$ & $0.175^{* * *}$ & 0.029 \\
\hline & $(16.051)$ & $(2.772)$ & $(0.349)$ \\
\hline$R^{2}$ & 0.049 & 0.153 & 0.171 \\
\hline Year fixed effects & No & No & No \\
\hline$N$ & 633 & 633 & 633 \\
\hline
\end{tabular}

Note. This table reports the estimates of the OLS regressions of target shareholders' probability of informed trading on good news ( $\mathrm{PIN}_{\text {good }}$ ) on deal- and firm-specific explanatory variables. The dependent variable is the average target $\mathrm{PIN}$ good over trading days -20 to -1 relative to the $M \& A$ announcement date (with the announcement date retrieved from Thomson ONE). We obtain daily probabilities of informed trading on good news from Brennan et al. (2018). The data set runs from 1990 to 2014. The Appendix provides the variable definitions. $t$-statistics, based on robust standard errors, are in parentheses. *,**, and ${ }^{* * *}$ indicate statistical significance at the $10 \%, 5 \%$, and $1 \%$ levels, respectively. $N$ denotes the number of observations.

TABLE 7 Takeover premiums over time

\begin{tabular}{|c|c|c|c|}
\hline \multirow[b]{2}{*}{ Year } & \multicolumn{2}{|c|}{ Premium } & \multirow[b]{2}{*}{$N$} \\
\hline & Mean & Median & \\
\hline 1985-1989 & 42.965 & 36.860 & 100 \\
\hline 1990-1994 & 45.356 & 39.300 & 132 \\
\hline 1995-1999 & 37.272 & 32.820 & 561 \\
\hline $2000-2004$ & 34.135 & 28.910 & 470 \\
\hline 2005-2009 & 31.645 & 26.620 & 351 \\
\hline 2010-2018 & 32.834 & 28.710 & 549 \\
\hline $1985-2018$ & 35.308 & 30.320 & 2,163 \\
\hline Trend & -0.438 & -0.439 & \\
\hline$p$-value & 0.000 & 0.000 & \\
\hline
\end{tabular}

Note. This table reports the mean and median takeover premiums over six subperiods. The sample consists of M\&As involving U.S. bidder and target firms from 1985 to 2018 obtained from Thomson ONE. We define Premium as the price paid per target share relative to the target's share price measured one week prior to the announcement of the deal. We retrieve premium information from Thomson ONE. We regress premium measures on a yearly time trend variable and an intercept. We report the coefficient and $p$-value of the time trend in the last two rows of this table. $N$ denotes the number of observations.

Conversely, if omitted variables cause the negative impact of the IT event dummy variables, then these dummies may also be significant in a Canadian context. We obtain a sample of Canadian M\&A deals from Thomson ONE and clean the sample using similar criteria to those outlined for the U.S. deals. We begin the analysis in 1990 due to a lack of deals in the 1980s. Our final Canadian M\&A sample consists of 751 deals with an average 20-day target abnormal stock runup of approximately $7.83 \%$. Table 9 provides the placebo test results. The dependent variable is the target abnormal stock run-up calculated over trading days -20 to -1 before the deal announcement date. 
TAB LE 8 Robustness of OLS regression of target run-ups

\begin{tabular}{|c|c|c|c|c|}
\hline Variables & $\begin{array}{l}\text { Deal anticipation } \\
\text { (1) }\end{array}$ & $\begin{array}{l}\text { Insider trading } \\
\text { (2) }\end{array}$ & $\begin{array}{l}\text { Deal anticipation } \\
\text { (3) }\end{array}$ & $\begin{array}{l}\text { Insider trading } \\
\text { (4) }\end{array}$ \\
\hline \multirow[t]{2}{*}{ Trend } & $-0.240^{* * *}$ & 0.125 & $-0.258^{* * *}$ & 0.072 \\
\hline & $(-7.029)$ & (1.050) & $(-8.431)$ & $(0.667)$ \\
\hline \multirow[t]{2}{*}{ Premium } & $0.038^{* * * *}$ & $0.034^{* * *}$ & & \\
\hline & (3.209) & (2.830) & & \\
\hline \multirow[t]{2}{*}{ Rumor } & $4.649^{* * * *}$ & $4.610^{* * * *}$ & $4.335^{* * *}$ & $4.238^{* * *}$ \\
\hline & (5.544) & (5.508) & $(5.465)$ & (5.369) \\
\hline \multirow[t]{2}{*}{ Toehold } & -1.204 & -0.910 & -0.979 & -0.965 \\
\hline & $(-0.845)$ & $(-0.630)$ & $(-0.840)$ & $(-0.826)$ \\
\hline \multirow[t]{2}{*}{ Cash financing } & 0.009 & $0.013^{*}$ & $0.013^{* * *}$ & $0.018^{* * *}$ \\
\hline & (1.282) & (1.821) & (1.977) & (2.598) \\
\hline \multirow[t]{2}{*}{ Hostile } & -0.436 & -0.661 & -0.541 & -0.908 \\
\hline & $(-0.215)$ & $(-0.329)$ & $(-0.318)$ & $(-0.537)$ \\
\hline \multirow[t]{2}{*}{ Poison pill } & -0.956 & -0.456 & -0.723 & -0.249 \\
\hline & $(-0.286)$ & $(-0.130)$ & $(-0.226)$ & $(-0.076)$ \\
\hline \multirow[t]{2}{*}{ Number of bidders } & -0.363 & -0.150 & $1.784^{*}$ & $1.982^{* *}$ \\
\hline & $(-0.360)$ & $(-0.149)$ & (1.833) & (2.031) \\
\hline \multirow[t]{2}{*}{ Market-to-book } & 0.056 & -0.019 & -0.130 & -0.181 \\
\hline & (0.317) & $(-0.111)$ & $(-0.808)$ & $(-1.125)$ \\
\hline \multirow[t]{2}{*}{ FCF } & $-5.865^{* *}$ & $-5.666^{* *}$ & $-6.027^{* *}$ & $-5.872^{* *}$ \\
\hline & $(-2.038)$ & $(-1.997)$ & $(-2.386)$ & $(-2.351)$ \\
\hline \multirow[t]{2}{*}{ Dividend yield } & -9.778 & -8.394 & -13.733 & -12.246 \\
\hline & $(-0.590)$ & $(-0.509)$ & $(-0.953)$ & $(-0.851)$ \\
\hline \multirow[t]{2}{*}{ Sales growth } & 0.000 & -0.006 & 0.002 & -0.004 \\
\hline & (0.013) & $(-0.343)$ & (0.129) & $(-0.261)$ \\
\hline \multirow[t]{2}{*}{ GR mismatch } & 0.071 & 0.197 & -0.327 & -0.193 \\
\hline & $(0.095)$ & $(0.264)$ & $(-0.492)$ & $(-0.291)$ \\
\hline \multirow[t]{2}{*}{ Leverage } & -0.027 & 0.142 & 0.376 & 0.535 \\
\hline & $(-0.070)$ & $(0.362)$ & (1.058) & (1.510) \\
\hline \multirow[t]{2}{*}{ Liquidity } & 0.120 & 0.639 & -0.831 & -0.436 \\
\hline & (0.103) & $(0.546)$ & $(-0.813)$ & $(-0.424)$ \\
\hline \multirow[t]{2}{*}{ Firm size } & $-0.678^{* * *}$ & $-0.621^{* * *}$ & $-0.808^{* * *}$ & $-0.740^{* * *}$ \\
\hline & $(-3.168)$ & $(-2.887)$ & $(-4.287)$ & $(-3.906)$ \\
\hline \multirow[t]{2}{*}{ Historical stock return } & $-7.556^{* *}$ & -3.671 & -3.498 & -0.070 \\
\hline & $(-1.973)$ & $(-0.903)$ & $(-1.013)$ & $(-0.019)$ \\
\hline \multirow[t]{2}{*}{ State } & 0.309 & 0.274 & 0.637 & 0.602 \\
\hline & $(0.532)$ & $(0.473)$ & (1.213) & (1.146) \\
\hline \multirow[t]{2}{*}{ Private bidder } & 1.372 & 1.570 & -1.084 & -0.931 \\
\hline & $(0.915)$ & (1.034) & $(-1.443)$ & $(-1.243)$ \\
\hline
\end{tabular}


TABLE 8 (Continued)

\begin{tabular}{|lllll|}
\hline & $\begin{array}{l}\text { Deal anticipation } \\
\text { Variables }\end{array}$ & $\begin{array}{l}\text { Insider trading } \\
(1)\end{array}$ & $\begin{array}{l}\text { Deal anticipation } \\
(2)\end{array}$ & $\begin{array}{l}\text { Insider trading } \\
(4)\end{array}$ \\
\hline Target-bidder ratio & $-0.565^{* *}$ & $-0.617^{* * *}$ & & \\
\hline IT event 1 (11/19/1988) & $(-2.416)$ & $(-2.657)$ & -1.404 \\
& & -1.445 & $(-0.852)$ \\
\hline IT event 2 (10/23/2000) & & $(-0.712)$ & $-2.561^{* *}$ \\
& & $-2.962^{* *}$ & $(-2.172)$ \\
\hline IT event 3 (08/14/2003) & & $(-2.370)$ & $-3.415^{* * *}$ \\
\hline IT event 4 (01/27/2009) & & $-2.804^{* *}$ & & $(-3.148)$ \\
\hline Constant & $(-2.483)$ & & -0.561 \\
\hline$R^{2}$ & $14.356^{* * * *}$ & -1.521 & $(-0.507)$ \\
\hline Year fixed effects & $(6.672)$ & $(-1.225)$ & & $10.650^{* * *}$ \\
\hline$N$ & 0.061 & $11.998^{* * *}$ & $12.967^{* * *}$ & $(4.804)$ \\
\hline
\end{tabular}

Note. This table reports further robustness tests for the OLS regressions of the target run-ups reported in Table 3. The sample consists of M\&As involving U.S. bidder and target firms from 1985 to 2018 obtained from Thomson ONE. We calculate target run-ups as abnormal stock returns over trading days -20 to -1 relative to the $M \& A$ announcement date retrieved from Thomson ONE. In Columns (1) and (2), we add the takeover premium (Premium). In Columns (3) and (4), we omit Target-bidder ratio enabling us to use a larger sample of 2,816 M\&A deals. The Appendix provides the variable definitions. $t$-statistics, based on robust standard errors, are in parentheses. ${ }^{*}{ }^{* *}$, and ${ }^{* * *}$ indicate statistical significance at the $10 \%, 5 \%$, and $1 \%$ levels, respectively. $\mathrm{N}$ denotes the number of observations.

Column (1) only includes a time trend variable, which is insignificant. Thus, unlike in the United States, we do not find that Canadian target stock run-ups are declining over time. In Column (2), we include the same deal-specific variables as for U.S. deals. ${ }^{11}$ Again, we find no significant time trend. The Target-bidder ratio has a negative impact on target runups similar to the U.S. findings. In Column (3), we add a dummy variable capturing an event that potentially strengthened insider trading rules in Canada. In particular, on January 30, 2003, Canadian authorities responded to the lack of enforcement of insider trading rules by proposing a national framework for securities regulation and by introducing Bill C-46 that provided specific Criminal Code offences in relation to insider trading and substantially increased the penalties (Canadian Securities Administrators [CSA], 2003). Integrated Market Enforcement Teams were established around the same period (King, 2009). We find a negative effect of these changes on Canadian target run-ups with the overall Trend now having a positive, but nonsignificant coefficient. In Column (4), we add U.S. IT event dummy variables capturing insider trading mitigation events in the United States after 1990 that serve as our placebo variables. We find that the U.S. IT event dummies do not have a significant negative impact on Canadian target run-ups. However, IT event 4 has a significant positive impact. Overall, this placebo test suggests that the negative impact of IT event dummies in a U.S. context is not spurious.

In an untabulated test, we verify whether the decline in target run-ups reflects a shift in shareholder value creation from target to bidding firms. We calculate run-ups and announcement returns for the publicly held bidders in the sample using a similar methodology to the one used for calculating the measures displayed in Table 1 . We do not

${ }^{11}$ Controlling for target-specific characteristics would unfortunately make the analysis of Canadian firms unfeasible due to too large loss of observations. 
TAB LE 9 OLS regression of Canadian target run-ups

\begin{tabular}{|c|c|c|c|c|}
\hline Variables & (1) & (2) & (3) & (4) \\
\hline \multirow[t]{2}{*}{ Trend } & -0.082 & -0.102 & 0.266 & -0.288 \\
\hline & $(-0.620)$ & $(-0.765)$ & $(1.619)$ & $(-0.890)$ \\
\hline \multirow[t]{2}{*}{ Rumor } & & 5.107 & 3.878 & 2.393 \\
\hline & & $(0.628)$ & $(0.440)$ & $(0.280)$ \\
\hline \multirow[t]{2}{*}{ Toehold } & & 0.686 & 0.642 & 0.399 \\
\hline & & $(0.285)$ & $(0.268)$ & $(0.165)$ \\
\hline \multirow[t]{2}{*}{ Cash financing } & & -0.007 & -0.010 & -0.011 \\
\hline & & $(-0.412)$ & $(-0.586)$ & $(-0.630)$ \\
\hline \multirow[t]{2}{*}{ Hostile } & & -5.049 & -5.798 & -5.713 \\
\hline & & $(-1.375)$ & $(-1.581)$ & $(-1.507)$ \\
\hline \multirow[t]{2}{*}{ Poison pill } & & 0.679 & 2.589 & 2.410 \\
\hline & & $(0.115)$ & $(0.446)$ & (0.401) \\
\hline \multirow[t]{2}{*}{ Number of bidders } & & 2.135 & 1.203 & 1.252 \\
\hline & & $(0.602)$ & $(0.337)$ & $(0.348)$ \\
\hline \multirow[t]{2}{*}{ Private bidder } & & 5.605 & 6.714 & 6.048 \\
\hline & & $(0.820)$ & $(0.985)$ & $(0.953)$ \\
\hline \multirow[t]{2}{*}{ Target-bidder ratio } & & $-1.667^{* * *}$ & $-1.618^{* * *}$ & $-1.626^{* * *}$ \\
\hline & & $(-3.432)$ & $(-3.344)$ & $(-3.352)$ \\
\hline \multirow[t]{2}{*}{ IT event Canada (01/30/2003) } & & & $-9.815^{* * *}$ & $-9.785^{*}$ \\
\hline & & & $(-3.513)$ & $(-1.882)$ \\
\hline \multirow[t]{2}{*}{ IT event $2(10 / 23 / 2000)$} & & & & 6.167 \\
\hline & & & & $(1.338)$ \\
\hline \multirow[t]{2}{*}{ IT event 3 (08/14/2003) } & & & & -0.328 \\
\hline & & & & $(-0.071)$ \\
\hline \multirow[t]{2}{*}{ IT event $4(01 / 27 / 2009)$} & & & & $5.642^{* *}$ \\
\hline & & & & $(2.112)$ \\
\hline \multirow[t]{2}{*}{ Constant } & $9.395^{* * *}$ & $12.562^{* *}$ & $15.197^{* * *}$ & $17.144^{* * *}$ \\
\hline & (3.689) & $(2.547)$ & $(3.025)$ & $(2.847)$ \\
\hline$R^{2}$ & 0.001 & 0.021 & 0.036 & 0.044 \\
\hline Year fixed effects & No & No & No & No \\
\hline$N$ & 751 & 751 & 751 & 751 \\
\hline
\end{tabular}

Note. This table reports the estimates of the OLS regressions of target firms' stock run-ups on deal-specific explanatory variables. The sample consists of M\&As involving Canadian bidder and target firms from 1985 to 2018 . We calculate target runups as abnormal stock returns over trading days -20 to -1 relative to the $M \& A$ announcement date retrieved from Thomson ONE. IT event dummy variables represent events associated with stricter insider trading regulation in a Canadian and U.S. context. The Appendix provides the variable definitions. $t$-statistics, based on robust standard errors, are in parentheses. *, **, and *** indicate statistical significance at the $10 \%, 5 \%$, and $1 \%$ levels, respectively. $N$ denotes the number of observations. 
find evidence of substantial bidder run-ups over the sample period (i.e., average of $-0.22 \%$, median of $-0.14 \%$ ). We also find no significant time trend in bidder run-up measures over the sample period. The $p$-value of the annual time trend coefficient obtained for the bidder run-up measured from trading day -20 to -1 is 0.81 . This suggests that the decrease in target run-ups does not arise from a shift in the distribution of (anticipated) takeover gains from targets toward bidders. Finally, we do not find a significant trend in bidder announcement returns over the research period. The $p$-value of the annual time trend coefficient obtained for bidder announcement stock returns is 0.189.

In another unreported test, we replicate the baseline regressions in Table 3 using insider purchases filed in accordance with Section 16(a) of the Securities and Exchange Act of 1934, obtained from Thomson Financial Insider Trading, as the dependent variable (Cline, Gokkaya, \& Liu, 2017; Foucault \& Fresard, 2014). It is important to note that these data only capture self-reported trades from corporate insiders, such as managerial executives. We do not find a significant impact of the four IT event dummy variables on these "legal" insider purchases, which is not surprising as the IT events reflect regulatory attempts at reducing illegal trading activity. Also unsurprisingly, the negative trend in target run-ups persists when controlling for these registered insider purchases.

Several studies document evidence in line with informed trading activity in the option markets (Augustin, Brenner, \& Subrahmanyam, 2019; Easley, O'Hara, and Srinivas, 1998; Mayhew, Sarin, \& Shastri, 1995). Thus, we reflected upon the possibility that the reduction in target run-ups may have resulted from a shift in insider trading activity from the stock to option markets. We believe this scenario is unlikely for the following two reasons. First, a move from stock to option markets in response to IT events would be based on the assumption that insider trading is less likely to be penalized in the option markets than in the stock markets. Academic and anecdotal evidence is inconsistent with this conjecture (Chakravarty, Gulen, \& Mayhew, 2004). In addition, even if a large number of insider trades would move from the stock to option markets following IT events, the effects of these option market trades would also be felt in the stock market due to well-established links between both markets (Hu, 2018; Stephan \& Whaley, 1990). Therefore, option market trades in target firm shares are likely to translate into target stock run-ups anyway, albeit potentially with short delays.

\section{6 | CONCLUSION}

M\&A target run-ups are well-established examples of preannouncement stock price patterns. The literature provides robust evidence that target firms exhibit a stock price increase in the period prior to the deal announcement (Dennis \& McConnell, 1986; Dodd, 1980; Keown \& Pinkerton, 1981; Meulbroek, 1992; Schwert, 1996).

In this paper, we report that this stylized fact has dramatically diminished over time. In our sample of U.S. domestic M\&As from 1985 to 2018, we find average target run-ups of $9.71 \%$ during the last half of the 1980 s, similar to previous studies. However, average run-ups declined to $8.33 \%$ by the last half of the 1990 s and continued to diminish during the 21st century. In the last subperiod of our research window, 2010-2018, average target run-ups are as low as $3.75 \%$ with a median of $2.18 \%$. In contrast, we observe that announcement period target abnormal stock returns increase over time resulting in a relatively constant magnitude of overall target stock returns associated with $M \& A$ announcements. In other words, our findings show that, over time, a smaller proportion of the target abnormal stock returns materialize prior to the announcement date and a larger proportion occurs around the announcement date.

The decline in target run-ups over time could potentially be attributed to a reduced ability of investors to anticipate $M \& A$ deals or to a decline in illegal insider trading activity in the market. Using a range of deal-and firm-specific proxies suggested in previous studies, we do not find evidence that the deal anticipation explanation can account for the decline in target run-ups, although we cannot completely rule out this explanation with the tests available. Consistent with an insider trading explanation, we find that the trend disappears when controlling for events likely associated with a reduction in the intensity of preannouncement insider trading. We conduct a wide range of robustness tests, including a placebo analysis on Canadian firms, to address concerns that our baseline results are a product of a 
spurious association between target run-ups and insider-trading-reducing events. Reassuringly, these tests all corroborate that a reduction in insider trading is the most likely explanation for the lower target run-ups.

\section{REFERENCES}

Acharya, V. V., \& Johnson, T. C. (2010). More insiders, more insider trading: Evidence from private equity buyouts. Journal of Financial Economics, 98(3), 500-523.

Alexandridis, G., Fuller, K. P., Terhaar, L., \& Travlos, N. G. (2013). Deal size, acquisition premia and shareholder gains. Journal of Corporate Finance, 20(1), 1-13.

Ambrose, B. W., \& Megginson, W. L. (1992). The role of asset structure, ownership structure, and takeover defenses in determining acquisition likelihood. Journal of Financial and Quantitative Analysis, 27(4), 575-589.

Asquith, P. (1983). Merger bids, uncertainty, and stockholder returns. Journal of Financial Economics, 11(1-4), 51-83.

Augustin, P., Brenner, M., \& Subrahmanyam, M. G. (2019). Informed options trading ahead of takeover announcements: Insider trading. Management Science, 65(12), 5697-5720.

Baker, M., \& Savaşoglu, S. (2002). Limited arbitrage in mergers and acquisitions. Journal of Financial Economics, 64(1), 91-115.

Bargeron, L. L., Schlingemann, F. P., Stulz, R. M., \& Zutter, C. J. (2008). Why do private acquirers pay so little compared to public acquirers? Journal of Financial Economics, 89(3), 375-390.

Betton, S., Eckbo, B. E., Thompson, R., \& Thorburn, K. S. (2014). Merger negotiations with stock market feedback. Journal of Finance, 69(4), 1705-1745.

Bhattacharya, U., \& Daouk, H. (2002). The world price of insider trading. Journal of Finance, 57(1), 75-108.

Bhattacharya, U., Daouk, H., Jorgenson, B., \& Kehr, K. (2000). When an event is not an event: The curious case of an emerging market. Journal of Financial Economics, 55(1), 69-101.

Bodnaruk, A., Massa, M., \& Simonov, A. (2009). Investment banks as insiders and the market for corporate control. Review of Financial Studies, 22(12), 4989-5026.

Brennan, M. J., Huh, S. W., \& Subrahmanyam, A. (2018). High frequency measures of informed trading and corporate announcements. Review of Financial Studies, 31(6), 2326-2376.

Brigida, M., \& Madura, J. (2012). Sources of target stock price run-up prior to acquisitions. Journal of Economics and Business, 64(2), 185-198.

Bris, A. (2005). Do insider trading laws work? European Financial Management, 11(3), 267-312.

Bruner, R. F. (2004). Applied mergers and acquisitions (Vol. 173). Hoboken, NJ: John Wiley \& Sons.

Buckley, F. H. (1997). The Canadian Keiretsu. Journal of Applied Corporate Finance, 9(4), 46-57.

Canadian Securities Administrators (CSA), (2003). Regulators release illegal insider trading report. Retrieved from https://www. securities-administrators.ca/aboutcsa. aspx? id= 402 .

Cao, C., Li, X., \& Liu, G. (2019). Political uncertainty and cross-border acquisitions. Review of Finance, 23(2), 439-470.

Chakravarty, S., Gulen, H., \& Mayhew, S. (2004). Informed trading in stock and option markets. Journal of Finance, 59(3), 12351257.

Chakravarty, S., \& McConnell, J. J. (1999). Does insider trading really move stock prices? Journal of Financial and Quantitative Analysis, 34(2), 191-209.

Cline, B. N., Gokkaya, S., \& Liu, X. (2017). The persistence of opportunistic insider trading. Financial Management, 46(4), 919964.

Comment, R., \& Schwert, G. W. (1995). Poison or placebo? Evidence on the deterrence and wealth effects of modern antitakeover measures. Journal of Financial Economics, 39(1), 3-43.

Custódio, C., Ferreira, M. A., \& Laureano, L. (2013). Why are U.S. Firms using more short-term debt? Journal of Financial Economics, 108(1), 182-212.

Dai, R., Massoud, N., Nandy, D. K., \& Saunders, A. (2017). Hedge funds in M\&A deals: Is there exploitation of insider information? Journal of Corporate Finance, 47, 23-45.

de Bodt, E., Cousin, J. G., \& Roll, R. (2017). Full-stock-payment marginalization in merger and acquisition transactions. Management Science, 64(2), 760-783.

Del Guercio, D., Odders-White, E. R., \& Ready, M. R. (2017). The deterrent effect of Securities and Exchange Commission's enforcement intensity on illegal insider trading: Evidence from run-up before news events. Journal of Law and Economics, 60(2), 269-307.

Dennis, D. K., \& McConnell, J. J. (1986). Corporate mergers and security returns. Journal of Financial Economics, 16(2), $143-187$.

Dodd, P. (1980). Merger proposals, management discretion and stockholder wealth. Journal of Financial Economics, 8(2), 105137.

Easley, D., Kiefer, N. M., O’Hara, M., \& Paperman, J. B. (1996). Liquidity, information, and infrequently traded stocks. Journal of Finance, 51(4), 1405-1436.

Easley, D., O'Hara, M., \& Srinivas, P. S. (1998). Option volume and stock prices: Evidence on where informed traders trade. Journal of Finance, 53(2), 431-465. 
Espahbodi, H., \& Espahbodi, P. (2003). Binary choice models and corporate takeover. Journal of Banking \& Finance, 27(4), 549574.

Foucault, T., \& Fresard, L. (2014). Learning from peers' stock prices and corporate investment. Journal of Financial Economics, 111(3), 554-577.

Fuller, K., Netter, J., \& Stegemoller, M. (2002). What do returns to acquiring firms tell us? Evidence from firms that make many acquisitions. Journal of Finance, 57(4), 1763-1793.

Gintschel, A., \& Markov, S. (2004). The effectiveness of regulation FD. Journal of Accounting and Economics, 37(3), $293-314$.

Golubov, A., Petmezas, D., \& Travlos, N. G. (2016). Do stock-financed acquisitions destroy value? New methods and evidence. Review of Finance, 20(1), 161-200.

Gupta, A., \& Misra, L. (1989). Public information and pre-announcement trading in takeover stocks. Journal of Economics and Business, 41(3), 225-233.

Hohenstein, K. A. (2006). Fair to all people: The SEC and the regulation of insider trading. Retrieved from http://www.sechistorical. org/museum/galleries/it/.

$\mathrm{Hu}$, J. (2018). Option listing and information asymmetry. Review of Finance, 22(3), 1153-1194.

Jabbour, A. R., Jalilvand, A., \& Switzer, J. A. (2000). Pre-bid price run-ups and insider trading activity: Evidence from Canadian acquisitions. International Review of Financial Analysis, 9(1), 21-43.

Jarrell, G. A., \& Poulsen, A. B. (1989). Stock trading before the announcement of tender offers: Insider trading or market anticipation? Journal of Law, Economics, \& Organization, 5(2), 225-248.

Jensen, M. C. (1986). Agency costs of free cash flow, corporate finance, and takeovers. American Economic Review, 76(2), 323329.

Jensen, M. C., \& Ruback, R. S. (1983). The market for corporate control: The scientific evidence. Journal of Financial Economics, 11(1-4), 5-50.

Karpoff, J. M., Schonlau, R. J., \& Wehrly, E. W. (2017). Do takeover defense indices measure takeover deterrence? Review of Financial Studies, 30(7), 2359-2412.

Keown, A. J., \& Pinkerton, J. M. (1981). Merger announcements and insider trading activity: An empirical investigation. Journal of Finance, 36(4), 855-869.

King, M. R. (2009). Prebid run-ups ahead of Canadian takeovers: How big is the problem? Financial Management, 38(4), 699726.

Lowry, M., Rossi, M., \& Zhu, Z. (2018). Informed trading by advisor banks: Evidence from options holdings. Review of Financial Studies, 32(2), 605-645.

Malatesta, P. H., \& Walkling, R. A. (1988). Poison pill securities: Stockholder wealth, profitability, and ownership structure. Journal of Financial Economics, 20(1), 347-376.

Malmendier, U., Moretti, E., \& Peters, F. S. (2018). Winning by losing: Evidence on the long-run effects of mergers. Review of Financial Studies, 31(8), 3212-3264.

Martin, K. J. (1996). The method of payment in corporate acquisitions, investment opportunities, and management ownership. Journal of Finance, 51(4), 1227-1246.

Mayhew, S., Sarin, A., \& Shastri, K. (1995). The allocation of informed trading across related markets: An analysis of the impact of changes in equity-option margin requirements. Journal of Finance, 50(5), 1635-1653.

Meulbroek, L. K. (1992). An empirical analysis of illegal insider trading. Journal of Finance, 47(5), 1661-1699.

Minenna, M. (2003). Insider trading, abnormal return and preferential information: Supervising through a probabilistic model. Journal of Banking \& Finance, 27(1), 59-86.

Netter, J. M., Poulsen, A. B., \& Hersch, P. L. (1988). Insider trading: The law, the theory, the evidence. Contemporary Economic Policy, 6(3), 1-13.

Newkirk, T. C., \& Robertson, M. A. (1998). September. Speech by SEC staff: Insider trading-A U.S. perspective. In the 16th International Symposium on Economic Crime, Cambridge, England: Jesus College.

Palepu, K. G. (1986). Predicting takeover targets: A methodological and empirical analysis. Journal of Accounting and Economics, 8(1), 3-35.

Schwert, G. W. (1996). Markup pricing in mergers and acquisitions. Journal of Financial Economics, 41(2), 153-192.

Schwert, G. W. (2000). Hostility in takeovers: In the eyes of the beholder? Journal of Finance, 55(6), 2599-2640.

Seitzinger, M. V. (2016). Federal Securities Law: Insider trading, Congressional Research Service. Retrieved from https://fas.org/sgp/ $\mathrm{crs} / \mathrm{misc} / \mathrm{RS} 21127 . \mathrm{pdf}$.

Song, M. H., \& Walkling, R. A. (1993). The impact of managerial ownership on acquisition attempts and target shareholder wealth. Journal of Financial and Quantitative Analysis, 28(4), 439-457.

Song, M. H., \& Walkling, R. A. (2000). Abnormal returns to rivals of acquisition targets: A test of the "Acquisition Probability Hypothesis." Journal of Financial Economics, 55(2), 143-171.

Steinberg, M. I. (2003). Insider trading regulation - a comparative analysis. The International Lawyer, 37, $153-171$. 
Stephan, J. A., \& Whaley, R. E. (1990). Intraday price change and trading volume relations in the stock and stock option markets. Journal of Finance, 45(1), 191-220.

Stulz, R. M., Walkling, R. A., \& Song, M. H. (1990). The distribution of target ownership and the division of gains in successful takeovers. Journal of Finance, 45(3), 817-833.

Thompson, J. H. (2013). A global comparison of insider trading regulations. International Journal of Accounting and Financial Reporting, 3(1), 1-23.

Ventoruzzo, M. (2015). Comparing insider trading in the United States and in the European Union: History and recent developments. European Company and Financial Law Review, 11(4), 554-593.

Weston, J. F., Mitchell, M. L., \& Mulherin, H. (2014). Takeovers, restructuring, and corporate governance. Essex, UK: Pearson Education Limited.

How to cite this article: Dutordoir M, Vagenas-Nanos E, Verwijmeren P, Wu B. A rundown of merger target run-ups. Financial Management. 2020;1-32. https://doi.org/10.1111/fima.12331

\section{APPENDIX: VARIABLE DEFINITIONS}

This Appendix presents the variables used in the empirical analysis (in alphabetical order) and describes their construction. All days represent trading days. We obtain balance sheet data from Compustat, stock price data from CSRP, and deal-specific information from Thomson ONE. All balance sheet items are measured at the fiscal year end before the deal announcement date (obtained from Thomson ONE) unless noted otherwise.

\begin{tabular}{|c|c|}
\hline Variable & Definition \\
\hline 1990-1994 & $\begin{array}{l}\text { An indicator variable that takes a value of one if the deal was announced after 01/01/1990 and } \\
\text { zero otherwise. }\end{array}$ \\
\hline 1995-1999 & $\begin{array}{l}\text { An indicator variable that takes a value of one if the deal was announced after 01/01/1995 and } \\
\text { zero otherwise. }\end{array}$ \\
\hline $2000-2004$ & $\begin{array}{l}\text { An indicator variable that takes a value of one if the deal was announced after } 01 / 01 / 2000 \text { and } \\
\text { zero otherwise. }\end{array}$ \\
\hline 2005-2009 & $\begin{array}{l}\text { An indicator variable that takes a value of one if the deal was announced after 01/01/2005 and } \\
\text { zero otherwise. }\end{array}$ \\
\hline 2010-2018 & $\begin{array}{l}\text { An indicator variable that takes a value of one if the deal was announced after 01/01/2010 and } \\
\text { zero otherwise. }\end{array}$ \\
\hline Cash financing & $\begin{array}{l}\text { The natural logarithm of one plus the percentage of the deal value paid in cash. The } \\
\text { corresponding data item from Thomson ONE is "Consideration: Percentage of Cash." }\end{array}$ \\
\hline Dividend yield & Dividend yield of the target. \\
\hline FCF & Free cash flow over total assets of the target. \\
\hline Firm size & $\begin{array}{l}\text { Total assets of the target converted into constant } 2010 \text { U.S. dollars using the U.S. Consumer } \\
\text { Price Index obtained from the OECD. }\end{array}$ \\
\hline GR mismatch & $\begin{array}{l}\text { An indicator variable that takes a value of one for targets with combinations of above average } \\
\text { growth, below average liquidity, and above average leverage, or below average growth, above } \\
\text { average liquidity, and below average leverage and zero otherwise. }\end{array}$ \\
\hline $\begin{array}{l}\text { Historical stock } \\
\quad \text { return }\end{array}$ & $\begin{array}{l}\text { Average daily excess returns of the target over the four years preceding the announcement } \\
\text { using the S\&P } 500 \text { as the market index. }\end{array}$ \\
\hline Hostile & $\begin{array}{l}\text { An indicator variable taking a value of one if the deal is hostile and zero otherwise. The } \\
\text { corresponding data item from Thomson ONE is "Deal Started as Unsolicited Flag (Y/N)." }\end{array}$ \\
\hline
\end{tabular}


(Continued)

\begin{tabular}{|c|c|}
\hline Variable & Definition \\
\hline $\begin{array}{l}\text { IT event } 1 \\
\qquad(11 / 19 / 1988)\end{array}$ & $\begin{array}{l}\text { An indicator variable that takes a value of one if the deal was announced after 11/19/1988 and } \\
\text { zero otherwise. }\end{array}$ \\
\hline $\begin{array}{l}\text { IT event } 2 \\
(10 / 23 / 2000)\end{array}$ & $\begin{array}{l}\text { An indicator variable that takes a value of one if the deal was announced after } 10 / 23 / 2000 \text {, and } \\
\text { zero otherwise. }\end{array}$ \\
\hline $\begin{array}{l}\text { IT event } 3 \\
(08 / 14 / 2003)\end{array}$ & $\begin{array}{l}\text { An indicator variable that takes a value of one if the deal was announced after 08/14/2003 and } \\
\text { zero otherwise. }\end{array}$ \\
\hline $\begin{array}{l}\text { IT event } 4 \\
(01 / 27 / 2009)\end{array}$ & $\begin{array}{l}\text { An indicator variable that takes a value of one if the deal was announced after 01/27/2009 and } \\
\text { zero otherwise. }\end{array}$ \\
\hline $\begin{array}{l}\text { IT event Canada } \\
(01 / 30 / 2003)\end{array}$ & $\begin{array}{l}\text { An indicator variable that takes a value of one if the deal was announced after 01/30/2003 and } \\
\text { zero otherwise. }\end{array}$ \\
\hline IT event & $\begin{array}{l}\text { An indicator variable that takes a value of one for deals announced in the window }[+90,+270] \\
\text { following one of the four IT events and zero for deals announced in the } 180 \text { trading days } \\
\text { before any of the IT events. }\end{array}$ \\
\hline
\end{tabular}

\section{Leverage}

Liquidity

Market-to-book

Number of bidders

Average leverage ratio of the target over the three years prior to the announcement date. "Number of Bidders."
Number of target The number of target firm financial advisors involved in the deal. The corresponding data item advisors from Thomson ONE is "Number of Target Advisors."

$\mathrm{PIN}_{\text {good }}$

Average liquidity ratio of the target over the three years prior to the announcement date.

Market-to-book ratio of common equity of the target.

The number of bidders involved in the deal. The corresponding data item from Thomson ONE is

Average daily posterior (conditional) probability of informed trading on good news ("informed buying") in the target firm's stock calculated over trading days -20 to -1 relative to the announcement date. Daily probabilities are calculated as in Brennan et al. (2018).

\section{Poison pill}

An indicator variable taking a value of one if the target has a poison pill approved by its board and zero otherwise. The corresponding data item from Thomson ONE is "Defensive Poison Pill Flag (Y/N)."

Private bidder

An indicator variable taking a value of one if the bidder is a private company and zero otherwise. The corresponding data item from Thomson ONE is "Acq Public Status."

Premium

The ratio of the offer price to the target stock price measured one week prior to the deal announcement. The corresponding data item from Thomson ONE is "Offer Price to Target Stock Price Premium 1 Week Prior."

Rumor

An indicator variable taking a value of one if there is a takeover rumor pertaining to the deal before the announcement date and zero otherwise. The corresponding data item from Thomson ONE is "Deal Began as Rumor."

Sales growth

State

Average growth (percentage change) in target firm sales over the three years prior to the announcement date.

An indicator variable that takes a value of one if the target's state of incorporation is Delaware and zero otherwise. We obtain this information from Compustat.

Target-bidder ratio The natural logarithm of the ratio of the target's market capitalization to the bidder's assets value. For publicly held bidders, we obtain total assets from Thomson ONE. For privately held bidders, we obtain total assets from Thomson ONE and Capital IQ (for Canadian bidders, we only use Thomson ONE).

Toehold

An indicator variable taking a value of one if the bidder owns target shares as of the announcement date and zero otherwise. The corresponding data item from Thomson ONE is "Percent of Shares Held at Announcement." 


\section{University Library}

\section{- M M I N E R VA A gateway to Melbourne's research publications}

Minerva Access is the Institutional Repository of The University of Melbourne

Author/s:

Dutordoir, M;Vagenas-Nanos, E;Verwijmeren, $\mathrm{P} ; \mathrm{Wu}, \mathrm{B}$

Title:

A rundown of merger target run-ups

Date:

2021

Citation:

Dutordoir, M., Vagenas-Nanos, E., Verwijmeren, P. \& Wu, B. (2021). A rundown of merger target run-ups. Financial Management, 50 (2), pp.487-518. https://doi.org/10.1111/ fima.12331.

Persistent Link:

http://hdl.handle.net/11343/252556

License:

cc-by-nc-nd 